\title{
Shallow Groundwater Quality Assessment and Its Suitability Analysis for Drinking and Irrigation Purposes
}

\author{
Muhammad Yousuf Jat Baloch ${ }^{1,2}\left(\mathbb{D}\right.$, Wenjing Zhang ${ }^{1,2, *(\mathbb{C}}$, Juanfen Chai ${ }^{1,2}$, Shuxin Li ${ }^{1,2}$, Muwaffaq Alqurashi ${ }^{3}{ }^{(1)}$,
} Gohar Rehman ${ }^{4}$, Aqil Tariq ${ }^{5}$ (), Shakeel Ahmed Talpur ${ }^{6}$, Javed Iqbal ${ }^{6}$, Mamoona Munir ${ }^{7}$ and Enas E. Hussein ${ }^{8}$ (I)

1 Key Laboratory of Groundwater Resources and Environment, Ministry of Education, Jilin University, Changchun 130021, China; engr.yousuf@yahoo.com (M.Y.J.B.); chaijf19@mails.jlu.edu.cn (J.C.); Lishuxin97@hotmail.com (S.L.)

2 College of New Energy and Environment, Jilin University, Changchun 130021, China

3 Department of Civil Engineering, College of Engineering, Taif University, Taif 21944, Saudi Arabia; m.gourashi@tu.edu.sa

4 College of Construction Engineering, Jilin University, Changchun 130026, China; geologist.gohar11@yahoo.com

5 State Key Laboratory of Information Engineering in Surveying, Mapping and Remote Sensing (LIESMARS), Wuhan University, Wuhan 430079, China; aqiltariq@whu.edu.cn

6 School of Environmental Studies, China University of Geosciences, Wuhan 430074, China; talpurshakill@yahoo.com (S.A.T.); jvcomsian@gmail.com (J.I.)

check for updates

Citation: Jat Baloch, M.Y.; Zhang, W.; Chai, J.; Li, S.; Alqurashi, M.; Rehman, G.; Tariq, A.; Talpur, S.A.; Iqbal, J.; Munir, M.; et al. Shallow Groundwater Quality Assessment and Its Suitability Analysis for Drinking and Irrigation Purposes. Water 2021, 13, 3361. https:// doi.org/10.3390/w13233361

Academic Editors: Chunhui Li, Zoe Li, Yurui Fan, Celso Augusto Guimarães Santos, Junliang Jin and Maurizio Barbieri

Received: 14 October 2021 Accepted: 22 November 2021 Published: 26 November 2021

Publisher's Note: MDPI stays neutral with regard to jurisdictional claims in published maps and institutional affiliations.

Copyright: (c) 2021 by the authors. Licensee MDPI, Basel, Switzerland. This article is an open access article distributed under the terms and conditions of the Creative Commons Attribution (CC BY) license (https:// creativecommons.org/licenses/by/ $4.0 /)$.
7 Department of Biological Sciences, International Islamic University, Islamabad 44000, Pakistan; mamoona.munir@iiu.edu.pk

8 National Water Research Center, P.O. Box 74, Shubra El-Kheima 13411, Egypt; enas_el-sayed@nwrc.gov.eg

* Correspondence: zhangwenjing80@hotmail.com

\begin{abstract}
For shallow groundwater, hydrogeochemical processes and quality assessment must be addressed because shallow groundwater is freely available in many parts of the globe. Due to recent anthropogenic activities and environmental changes in Sakrand, Sindh, Pakistan, the groundwater is extremely vulnerable. To provide safe drinking and agricultural water, hydrogeochemical analysis is required. Ninety-five groundwater samples were analyzed using agricultural and drinking indices to determine the hydrogeochemical parameters using multivariate analysis such as Pearson correlations, principal component cluster analysis, as well as Piper diagrams and Gibbs plot for drinking and agricultural indices. An abundance of ions was observed through the statistical summary; however, cations and anions were recorded in the orders $\mathrm{Na}^{+}>\mathrm{Ca}^{2+}>\mathrm{Mg}^{2+}>\mathrm{K}^{+}$and $\mathrm{HCO}_{3}{ }^{-}>\mathrm{Cl}^{-}>\mathrm{SO}_{4}{ }^{2-}$ $>\mathrm{NO}_{3}{ }^{-}>\mathrm{F}^{-}$. The hydrogeochemical process used to quantify the major reactions occurring in the groundwater system showed rock dominance; the Piper diagrams evaluated the water type. A mixed pattern of calcium, magnesium, and chloride ions $\left(\mathrm{Ca}^{2+}-\mathrm{Mg}^{2+}-\mathrm{Cl}^{-}\right.$type $)$was observed. Additionally, the ion exchange method showed an excess of bicarbonate ions due to carbonic acid weathering. The water quality index (WQI) resulted $32.6 \%$ of groundwater being unsuitable for human consumption; however, the United States Salinity Laboratory (USSL) diagram showed $60 \%$ of samples were unsuitable for irrigation due to high salinity and the Wilcox diagram depicted $5 \%$ of samples lying in the unsuitable region. Most of the water samples were suitable for drinking; only a few samples were unsafe for drinking purposes for children due to the high hazard index.
\end{abstract}

Keywords: hydrogeochemical facies; water-rock interaction; groundwater; water quality index (WQI); multivariate analysis; health risk rate (HRR)

\section{Introduction}

Water is the most basic and critical requirement for human survival. With the increasing expansion of industrialization and urbanization, ensuring the sustainable use of water resources to solve the supply-demand gap remains a global problem [1]. Groundwater has been widely used for drinking, irrigation, and numerous industrial applications across the 
world as an essential source of water supply [2,3]. Groundwater is widely utilized for drinking and irrigation in Pakistan, particularly in the south [4]. The district's socioeconomic environment (Shaheed Benazirabad) implies that Sakarand's people are highly reliant on agriculture for food and money [5], and the majority of the agriculture is dependent on groundwater irrigation [6]. Despite its geological protection, groundwater, like surface water, is susceptible to contamination. Because of the advancement of human activities, industrial and agriculture activities possible sources of groundwater pollution rose in the previous decade [7-12]. Agriculture, through erosion and chemical runoff, is a major contributor to the deterioration of surface and groundwater resources [13]. The necessity to produce enough food has a global impact on agricultural techniques such as intensification, which requires more irrigation, and the widespread application of fertilizers and pesticides. Nutrients and pesticides can contaminate surface and groundwater if these activities are not properly managed $[14,15]$. The generation of trash and its manner of disposal in urban and industrial regions is one of the activities that produces huge amounts of pollutants that will be discovered in the natural environment without appropriate treatment and can reach groundwater [11,16].

Water quality evaluation has become inevitable in water resource management as a result of the increased degradation of water quality in connection to human activities. The most frequent method of assessing water quality was to compare the contents of water quality parameters to their standard levels for a given purpose [17-21]. The hydrochemical properties of groundwater might be used to identify possible changes in groundwater quality by plotting main ion concentrations on various graphical representations, such as a Piper diagram, Gibbs plot, Na-normalization ratio, and so on, and using statistical analysis [2,22]. A water quality index (WQI) is another method for measuring and classifying water quality that is becoming increasingly popular. A WQI has the benefit of utilizing mathematical techniques to convert water quality parameter levels into an indicator score. Numerous organizations and scholars [23-25] have created and utilized several multivariate statistical analysis and groundwater numerical modeling to help public authorities manage groundwater remediation water indices to characterize the appropriateness of various uses of water resources [25]. These approaches, including principal component analysis (PCA), cluster analysis (CA), and discriminant analysis, are often used to solve multivariate issues and are broadly used in geology and hydrology.

Shallow groundwater is a popular supply of household water in many Pakistani suburbs and rural regions [26]. However, due to heavy human activity, its quality is declining, potentially harming human health and the ecosystem. Numerous investigations have indicated anthropogenic pollution of groundwater resources in many locations, such as agricultural contamination (As, Ni, pesticides, etc.) found in the groundwater of Multan's most heavily irrigated regions [27]. In Sialkot, groundwater is highly contaminated with $\mathrm{Zn}, \mathrm{Fe}$, and $\mathrm{Pb}$ because of leaching from contaminated soil [28], and a similar case was reported in Lower Dir (northern Pakistan), where high levels of $\mathrm{Cr}, \mathrm{Pb}, \mathrm{Cd}, \mathrm{Co}$, and $\mathrm{Fe}$ were found in groundwater whose major contributor is the local geology [29]. Baig et al. (2009) assessed the water quality parameters in the Jamshoro area of Pakistan, finding that $\mathrm{Na}^{+}, \mathrm{K}^{+}$, and $\mathrm{SO}_{4}{ }^{2-}$ concentrations were increased due to the semi-arid environment and human interferences (intensive agriculture) [30].

According to Memon et al. (2011) TDS, EC, alkalinity, hardness, and $\mathrm{Na}^{+}$levels in all three water bodies (dug wells, shallow pumps, and water supply systems) were above the WHO's acceptable limits. The high concentration of $\mathrm{Na}^{+}$, as well as the high concentration of Iron, was a serious concern in the Thar district's drilled wells and shallow pumps, particularly in district Badin [31]. Lanjwani et al. (2020) found significant concentrations of main ions such as $\mathrm{Ca}^{2+}, \mathrm{Mg}^{2+}, \mathrm{Na}^{+}, \mathrm{Cl}^{-}, \mathrm{SO}_{4}{ }^{2-}$, and $\mathrm{HCO}_{3}{ }^{-}$in 36 percent of water samples collected from the district of Larkana, Sindh, as well as poor water quality based on WQI, and a polluted index of $\mathrm{Pb}, \mathrm{Ni}$, and $\mathrm{Cd}$ [32]. In lower southern Sindh, Shahab et al. (2016) observed groundwater pollution with significant concentrations of EC, TDS, $\mathrm{Na}^{+}$, $\mathrm{Cl}^{-}, \mathrm{SO}_{4}{ }^{2-}, \mathrm{HCO}_{3}{ }^{-}, \mathrm{As}$, and $\mathrm{Fe}[33]$. 
The water quality in Sindh province is deteriorating day by day. Due to rising population density, significant groundwater extraction for agriculture, harsh climatic conditions, and dwindling water tables in Sindh's Sakrand district, it became critical to analyze the region's water quality for drinking and irrigation. Thus far, hydrochemical research has not been done yet in the Sakrand area of Sindh to assess water quality for drinking and agricultural purposes. The present study aims to identify the physical and chemical characteristics of groundwater to assess the drinking and agricultural water quality of a small, densely inhabited, agriculturally rich region. This study's findings would be useful information for managing groundwater resources as well as for seeking an effective approach to address the present health and agricultural issues in Sakrand, Sindh. It may also assist in the implementation of a sound management method in other regions. Furthermore, this study could also provide a reference for several methodologies to reveal hydrogeochemical processes and evaluate groundwater quality.

\section{Description of the Study Area}

\subsection{Study Area}

The study area is located in the Sindh province it is the second-most populous province in Pakistan. Sakrand is a town in Sindh province which lies in district Shaheed Benazirabad, previously known as Nawabshah; the location is about $26^{\circ} 8^{\prime} 17^{\prime \prime} \mathrm{N} 68^{\circ} 16^{\prime} 23^{\prime \prime} \mathrm{E}$; the crosssection and peizomatric map is shown in Figure 1. The elevation of the study area is $25 \mathrm{~m}$ $(82 \mathrm{ft})$, the climate is predominantly hot and dry, and the temperature ranges from below $40^{\circ} \mathrm{F}$ to above $117^{\circ} \mathrm{F}$. It can be classified an arid subtropical zone, i.e., very cold and dry in winter and very hot, arid, humid, and windy in summer. The summer temperatures can reach $53^{\circ} \mathrm{C}$, while winter temperatures can fall as low as $1^{\circ} \mathrm{C}$. However, the average annual precipitation varies from $200 \mathrm{~mm}$ to $300 \mathrm{~mm}$ [34], with the majority occurring during the monsoon season, which occurs in July, August, and September. Wheat and cotton are the most widely farmed crops in the region and are cultivated in Sindh's delta plain [35].

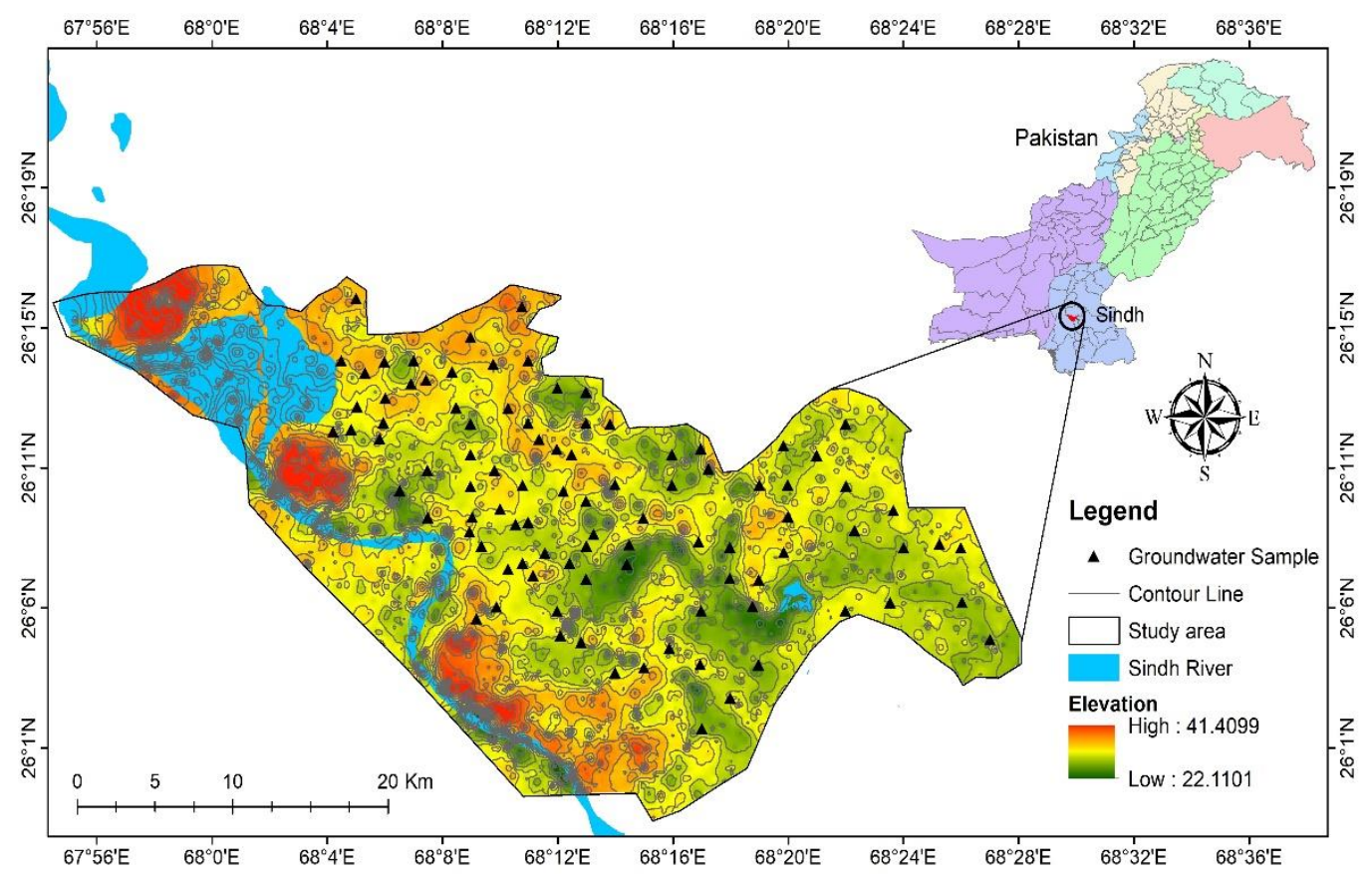

Figure 1. Groundwater sampling points and geological formation of Sakrand, Sindh, Pakistan.

\subsection{Geology and Hydrogeology}

Sakrand is in the southern part of the Indus plain; thus, the groundwater resources are from the Indus river. The groundwater along the small strip of the Indus river is usually less saline than other major parts, where the water is generally very saline [33]. Low cropping 
intensity, canal seepage, and lateral channels produce salinization. Chemical investigation showed about $15 \%$ of the studied area is moderately to extremely saline, and saline-alkaline soil accounts for more than $5.5 \%$ of the total landmass [36]. The groundwater table ranges from $1.5-12 \mathrm{~m}$ and the average depth is $4.53 \mathrm{~m}$. The flow in the upper and middle sections is more south-westerly, while in the middle and lower sections it is more westerly, toward the Indus river. Sand is usually the primary component of a uniform, non-artesian, and transmissive aquifer.

\section{Materials and Methods}

\subsection{Sample Collection and Analysis}

Ninty-five groundwater samples were collected from shallow aquifer $(<35 \mathrm{~m})$ at Sakrand, Sindh, Pakistan. Groundwater samples were collected, rinsed, washed with 10\% $\mathrm{HCl}$ solution and tested for the analysis. The bottles were soaked with double-deionized water after being rinsed. Collected samples were examined for drinking and agriculture purposes. Physicochemical characteristics were tested at Pakistan Council of Research in Water Resources, (PCRWR) as follows: pH determined by pH 720 WTW Series meter, electrical conductivity (EC), total dissolved solids (TDS), and temperature were measured by EC-TDS-Temp (RS232C/Meter CON $110 \mathrm{~m}$ ). Total alkalinity was calculated by using acid titration in samples containing methyl-orange. Titration methods were used for $\mathrm{Cl}^{-}$ and $\mathrm{HCO}_{3}{ }^{-}$; however, a turbidity meter was used to measure the turbidity whereas the major anions such as $\left(\mathrm{NO}_{3}{ }^{-}\right)$and sulfate $\left(\mathrm{SO}_{4}{ }^{2-}\right)$, were determined by ultraviolet-visible (UV-VIS) spectrophotometer (Analytik Jena, Jena, Germany). A flame photometer (PFP7, Cambridge shire, UK) was used to measure the cations, such as $\mathrm{Mg}^{2+}, \mathrm{Ca}^{2+}, \mathrm{K}^{+}, \mathrm{Na}^{+}$, and Fe.

\subsection{Statistical Parameters}

Statistical analysis plays an integral role in evaluating the data set for the different operations of data analysis, performed to determine the correlation plots. Statistical techniques using IBM SPSS 20 software's and the mean values, including minimum, maximum, median percentile, and standard deviation values of the parameters were also determined in box plots. The multivariate analysis was done by principal component analysis (PCA) and cluster analysis (CA) using R-package R v.4. to determine the primary factors that influence groundwater quality and its suitability for drinking and irrigation. PCA [37] is a strong method for examining patterns of correlations between groups of variables. The Golden Software Grapher 18.3 was used for the pictorial representation of the Piper, showing the chemistry of the water samples collected from the study area. The study area map was created by ARC.GIS 10.7.1 for data set interpretation. Additionally, MS Excel 2019 were also used for the U.S. Salinity Laboratory (USSL) and Wilcox diagram. The World Health Organization (WHO) guidelines were used to determine the WQI, and the calculation was carried out using a weighted arithmetic index [3].

\subsection{Assessment of Groundwater Quality \\ 3.3.1. For Drinking}

The water quality index (WQI) is used for the checking of the suitability of water for drinking purposes. The most comprehensive method for determining the quality of groundwater is water quality assessment; thus, WHO standards were used to assess groundwater quality. The aggregate effects of various chemical parameters on groundwater were checked thoroughly [38].

WQI is calculated in three steps; the weight assessment was done in the first step. Weight is represented as wi for all parameters. The parameters were (EC, $\mathrm{pH}, \mathrm{TDS}, \mathrm{HCO}_{3}{ }^{-}$, $\left.\mathrm{Cl}^{-}, \mathrm{SO}_{4}{ }^{2-}, \mathrm{Ca}^{2+}, \mathrm{Mg}^{2+}, \mathrm{Na}^{+}, \mathrm{K}^{+}, \mathrm{NO}_{3}{ }^{-}, \mathrm{F}^{-}, \mathrm{Fe}, \mathrm{As}\right)$ in order of their relative weight importance. Overall assessment for quality was carried out. While evaluating the quality of groundwater, weights were assigned between 1 to 5 , based on the importance of their role [39]. 
In step number two, the relative weights were calculated for each parameter using Equation (1).

$$
\mathrm{W}_{\mathrm{i}}=\frac{\mathrm{W}_{\mathrm{i}}}{\sum_{\mathrm{i}}^{\mathrm{n}} \mathrm{W}_{\mathrm{i}}}
$$

Here, relative weight is $W_{i}$ and the weight of each parameter is $w_{i}$ while $n$ is the total number of parameters studied.

The quality rating scale $q_{i}$ is computed in step number three for each parameter using Equation (2).

$$
\mathrm{q}_{\mathrm{i}}=\frac{\mathrm{C}_{\mathrm{i}}}{\mathrm{S}_{\mathrm{i}}} \times 100
$$

Hence, $C_{i}$ represents the concentration of each parameter $(\mathrm{mg} / \mathrm{L})$; $S_{i}$ is the standard of WHO Table 1 , and $\mathrm{q}_{\mathrm{i}}$ is the quality index [40].

Table 1. WHO standards, weights, and relative weights of various parameters.

\begin{tabular}{cccc}
\hline Parameters & WHO Standards $\left(\mathbf{S}_{\mathbf{i}}\right)$ & $\begin{array}{c}\text { Weight }\left(\mathbf{w}_{\mathbf{i}}\right) \\
\text { Total } \mathbf{~ 5 2}\end{array}$ & $\begin{array}{c}\text { Relative Weight }\left(\mathbf{W}_{\mathbf{i}}\right) \\
\text { Total } \mathbf{~} \mathbf{1}\end{array}$ \\
\hline $\mathrm{EC}(\mu \mathrm{S} / \mathrm{cm})$ & 1000 & 4 & 0.08 \\
$\mathrm{pH}$ & $6.5-8.5$ & 4 & 0.08 \\
$\mathrm{TDS}(\mathrm{mg} / \mathrm{L})$ & 1000 & 5 & 0.09 \\
$\mathrm{HCO}_{3}^{-}(\mathrm{mg} / \mathrm{L})$ & 250 & 4 & 0.08 \\
$\mathrm{Cl}^{-}(\mathrm{mg} / \mathrm{L})$ & 250 & 4 & 0.08 \\
$\mathrm{SO}_{4}^{2-}(\mathrm{mg} / \mathrm{L})$ & 250 & 3 & 0.06 \\
$\mathrm{Ca}^{2+}(\mathrm{mg} / \mathrm{L})$ & 200 & 4 & 0.08 \\
$\mathrm{Mg}^{2+}(\mathrm{mg} / \mathrm{L})$ & 150 & 4 & 0.08 \\
$\mathrm{Na}^{+}(\mathrm{mg} / \mathrm{L})$ & 200 & 5 & 0.09 \\
$\mathrm{~K}^{+}(\mathrm{mg} / \mathrm{l})$ & 12 & 5 & 0.09 \\
$\mathrm{NO}_{3}^{-}(\mathrm{mg} / \mathrm{L})$ & 10 & 3 & 0.06 \\
$\mathrm{~F}^{-}(\mathrm{mg} / \mathrm{L})$ & 1.5 & 3 & 0.06 \\
$\mathrm{Fe}(\mathrm{mg} / \mathrm{L})$ & 0.3 & 2 & 0.03 \\
$\mathrm{As}(\mathrm{ppb})$ & 10 & 2 & 0.03 \\
\hline
\end{tabular}

Furthermore, summation of sub-indexes is done by following Equations (3) and (4).

$$
\begin{aligned}
& \mathrm{SI}_{\mathrm{i}}=\mathrm{W}_{\mathrm{i}} \times \mathrm{q}_{\mathrm{i}} \\
& \mathrm{WQI}=\sum_{\mathrm{i}=1}^{\mathrm{n}} \mathrm{SI}_{\mathrm{i}}
\end{aligned}
$$

$\mathrm{SI}_{\mathrm{i}}$ and $\mathrm{W}_{\mathrm{i}}$ are sub-indexes and relative weights for the ith parameter, respectively; $\mathrm{q}_{\mathrm{i}}$, on the other hand, is a rating based on the ith parameter's concentration.

\subsubsection{For Irrigation}

The typical indicators for assessing groundwater for irrigation-sodium absorption ratio (SAR), soluble sodium percentage (SSP), permeability index (PI), magnesium ratio (MAR), and Kelley's ratio (KR) were computed.

\section{(a) Sodium Adsorption Ratio (SAR)}

The suitability indicator for water irrigation is the sodium adsorption ratio (SAR). In addition to the indication, it also checks on the chances of sodium hazard of the collected irrigation water [41] and is calculated by Equation (5).

$$
\mathrm{SAR}=\frac{\mathrm{Na}^{+}}{\sqrt{\frac{\mathrm{Ca}^{2+}+\mathrm{Mg}^{2+}}{2}}}
$$


(b) Soluble Sodium Percentage (SSP)

The Soluble Sodium Percent (SSP) for groundwater was calculated by Equation (6).

$$
\mathrm{SSP}=\frac{100 \times\left(\mathrm{K}^{+}+\mathrm{Na}^{+}\right)}{\mathrm{Ca}^{2+}+\mathrm{Na}^{+}+\mathrm{Mg}^{2+}+\mathrm{K}^{+}}
$$

(c) Permeability Index (PI)

Groundwater suitability for irrigation may also be determined by using the (PI), which is calculated employing Equation (7).

$$
\mathrm{PI}=\frac{\left(\mathrm{Na}^{+}+\sqrt{\mathrm{HCO}_{3}^{-}}\right)}{\left(\mathrm{Ca}^{2+}+\mathrm{Mg}^{2+}+\mathrm{Na}^{+}\right)} \times 100
$$

(d) Magnesium Ratio (MAR)

The extra or excess amount of magnesium over magnesium and calcium is known as MAR. If the magnesium is present in excess in the soil, it disastrously affects the quality of the soil. If the hazard value of magnesium increases up to $50 \%$, it adversely affects the quality of soil, and the soil becomes more alkaline. This alkalinity directly affects crop yields [42]. The magnesium ratio was calculated by Equation (8).

$$
\mathrm{MAR}=\frac{\mathrm{Mg}^{2+}}{\mathrm{Mg}^{2+}+\mathrm{Ca}^{2+}} \times 100
$$

\section{(e) Kelly Ratio (KR)}

Kelly proposed another crucial factor to calculate groundwater appropriateness for irrigation, known as the Kelly ratio (KR), which is calculated by Equation (9). If the value of $(\mathrm{KR})$ is greater than 1 it refers to a surplus of sodium in groundwater, and if it is less than 1 it shows fitness of groundwater for irrigation.

$$
\mathrm{KR}=\frac{\mathrm{Na}^{+}}{\mathrm{Mg}^{2+}+\mathrm{Ca}^{2+}}
$$

\subsection{Health Risk Assessment}

Health risk assessment generally refers to the process in which there is an estimation and calculation of deleterious effects on human health. These adverse effects may be due to contaminations to which humans are being exposed. Specifically, contaminants in water severely impact human health; thus, the physical, biological, and chemical pollution of water causes serious health issues [43]. Generally, humans are exposed to water contaminants by domestic usage of water through direct consumption or indirect uptake during a bath, etc. Some water vapors are inhaled, and this is another pathway for the uptake of contaminants of water $[44,45]$.

Pakistan is one of the developing countries in Asia facing different health issues due to poor water quality. The Pakistan Council of Research Water Resources (PCRWR) reported in 2008 that about $40 \%$ of illnesses in Pakistan are due to the drinking of contaminated water and $20-40 \%$ of hospitalizations are because of various water-borne diseases [46].

The United States Environmental Protection Agency (USEPA) devised a risk assessment process for human health. There are four steps for HRR assessment [47]. (1) Identification of hazards, (2) Assessment for the dose-response, (3) Assessment for exposure, (4) Characterization of risk. The for-mulas separately calculate the risk for children and adults by Equation (10)

$$
\mathrm{CDI}=\frac{\mathrm{C}_{\mathrm{w}} \times \mathrm{IR} \times \mathrm{EF} \times \mathrm{ED}}{\mathrm{BW} \times \mathrm{AT}}
$$


CDI is the abbreviation for Chronic Daily Intake. Its units are $\mathrm{mg} / \mathrm{kg} /$ day. Other symbols are explained and elaborated in Table 2.

Table 2. Exposure parameters for health risk rate assessment.

\begin{tabular}{|c|c|c|c|c|}
\hline $\begin{array}{c}\text { Exposure } \\
\text { Parameters }\end{array}$ & Description & Unit & $\begin{array}{l}\text { Value (For } \\
\text { Adults) }\end{array}$ & $\begin{array}{l}\text { Value (For } \\
\text { Children) }\end{array}$ \\
\hline $\mathrm{Cw}$ & $\begin{array}{l}\text { Contaminant } \\
\text { Concentration in } \\
\text { Water }\end{array}$ & $\mathrm{mg} / \mathrm{L}$ & - & - \\
\hline IR & Ingestion Rate & L/day & 2 L/day & $1 \mathrm{~L} /$ day \\
\hline $\mathrm{EF}$ & $\begin{array}{l}\text { Exposure } \\
\text { Frequency }\end{array}$ & Days/year & 365 days/year & 365 days/year \\
\hline ED & $\begin{array}{l}\text { Exposure } \\
\text { Duration }\end{array}$ & Years & 30 Years & 6 Years \\
\hline BW & Body Weight & $\mathrm{Kg}$ & $70 \mathrm{~kg}$ & $15 \mathrm{~kg}$ \\
\hline AT & $\begin{array}{c}\text { Average } \\
\text { Exposure Time }\end{array}$ & Days & 10,950 & 2190 \\
\hline
\end{tabular}

The hazard quotient (HQ) calculated by Equation (11) to determine the rate of noncarcinogenic risk in adults and children.

$$
\mathrm{HQ}=\mathrm{HI}=\frac{\mathrm{CDI}}{\mathrm{RfD}}
$$

Here RfD stands for reference dose of a specific element specified in this study; these elements are $\mathrm{Fe}$ and $\mathrm{As}(\mathrm{mg} / \mathrm{kg} /$ day).

The value of RfD for arsenic metal is 0.0003 and for iron is 0.7 . To calculate the carcinogenic risk for the carcinogenic contaminants we use Equation (12).

$$
\mathrm{CR}=\mathrm{CDI} \times \mathrm{SF}
$$

SF stands for slope factor. If the value of HQ exceeds 1 and that of CR exceeds $1 \times 10^{6}$ then the risk is dangerous, and there is a need for working on reducing this risk.

\section{Results and Discussion}

\subsection{Hydrochemical Parameters of Groundwater}

The prime qualities are the physicochemical parameters for identifying the quality, nature, and type of groundwater [48]. This study used statistical analysis to better display the vast data set, revealing the minimum, maximum, mean, median, standard deviation, and percentiles shown in Table 3, with the associated box plot given in Figure 2. The summary of the physicochemical parameters and the hydrochemical properties of groundwater have been statistically evaluated, and the findings compared with World Health Organization standards. 
Table 3. Statistical summary of groundwater.

\begin{tabular}{|c|c|c|c|c|c|c|c|}
\hline $\begin{array}{c}\text { Physiochemical } \\
\text { Parameters }\end{array}$ & Minimum & Maximum & Mean & Median & $\begin{array}{l}\text { Standard } \\
\text { Deviation }\end{array}$ & $\begin{array}{c}\text { Percentiles } \\
\text { (95) }\end{array}$ & $\begin{array}{c}\text { WHO } \\
\text { Standards }\end{array}$ \\
\hline $\mathrm{EC}(\mu \mathrm{S} / \mathrm{cm})$ & 470 & 7086 & 1829.57 & 1655 & 1138.65 & 4028 & 1000 \\
\hline $\mathrm{pH}$ & 6.5 & 8.1 & 7.17 & 7.1 & 0.43 & 8 & $6.5-8.5$ \\
\hline Turbidity (NTU) & 0 & 3.9 & 2.56 & 2.7 & 0.78 & 3.82 & 5 \\
\hline TDS (mg/L) & 301 & 4493 & 1116.93 & 1022 & 643.69 & 2207 & 1000 \\
\hline Alkalinity $(\mathrm{mg} / \mathrm{L})$ & 1.8 & 28 & 7.63 & 6.7 & 4.88 & 17.2 & - \\
\hline $\mathrm{TH}(\mathrm{mg} / \mathrm{L})$ & 130 & 1800 & 517.06 & 500 & 282.2 & 1022.2 & 300 \\
\hline $\mathrm{HCO}_{3}-(\mathrm{mg} / \mathrm{L})$ & 90 & 1400 & 387.77 & 340 & 243.78 & 860 & 250 \\
\hline $\mathrm{Cl}^{-}(\mathrm{mg} / \mathrm{L})$ & 70 & 800 & 196.90 & 186 & 108.52 & 399 & 250 \\
\hline $\mathrm{SO}_{4}{ }^{2-}(\mathrm{mg} / \mathrm{L})$ & 23 & 831 & 165.28 & 160 & 101.52 & 330 & 250 \\
\hline $\mathrm{Ca}^{2+}(\mathrm{mg} / \mathrm{L})$ & 24 & 420 & 101.70 & 80 & 63.94 & 210 & 200 \\
\hline $\mathrm{Mg}^{2+}(\mathrm{mg} / \mathrm{L})$ & 15 & 488 & 69.12 & 61 & 54.64 & 142.8 & 150 \\
\hline $\mathrm{Na}^{+}(\mathrm{mg} / \mathrm{L})$ & 39 & 772 & 158.54 & 146 & 104.61 & 335 & 200 \\
\hline $\mathrm{K}^{+}(\mathrm{mg} / \mathrm{L})$ & 0.6 & 25.5 & 4.52 & 3.5 & 3.93 & 13.06 & 12 \\
\hline $\mathrm{NO}_{3}-(\mathrm{mg} / \mathrm{L})$ & 0 & 3.3 & 0.925 & 0.86 & 0.49 & 2.42 & 10 \\
\hline $\mathrm{F}^{-}(\mathrm{mg} / \mathrm{L})$ & 0.03 & 0.77 & 0.25 & 0.23 & 0.11 & 0.44 & 1.5 \\
\hline $\mathrm{Fe}(\mathrm{mg} / \mathrm{L})$ & 0 & 0.43 & 0.062 & 0.05 & 0.07 & 0.244 & 0.3 \\
\hline As (ppb) & 0 & 10 & 1.52 & 0 & 3.18 & 10 & 10 \\
\hline
\end{tabular}
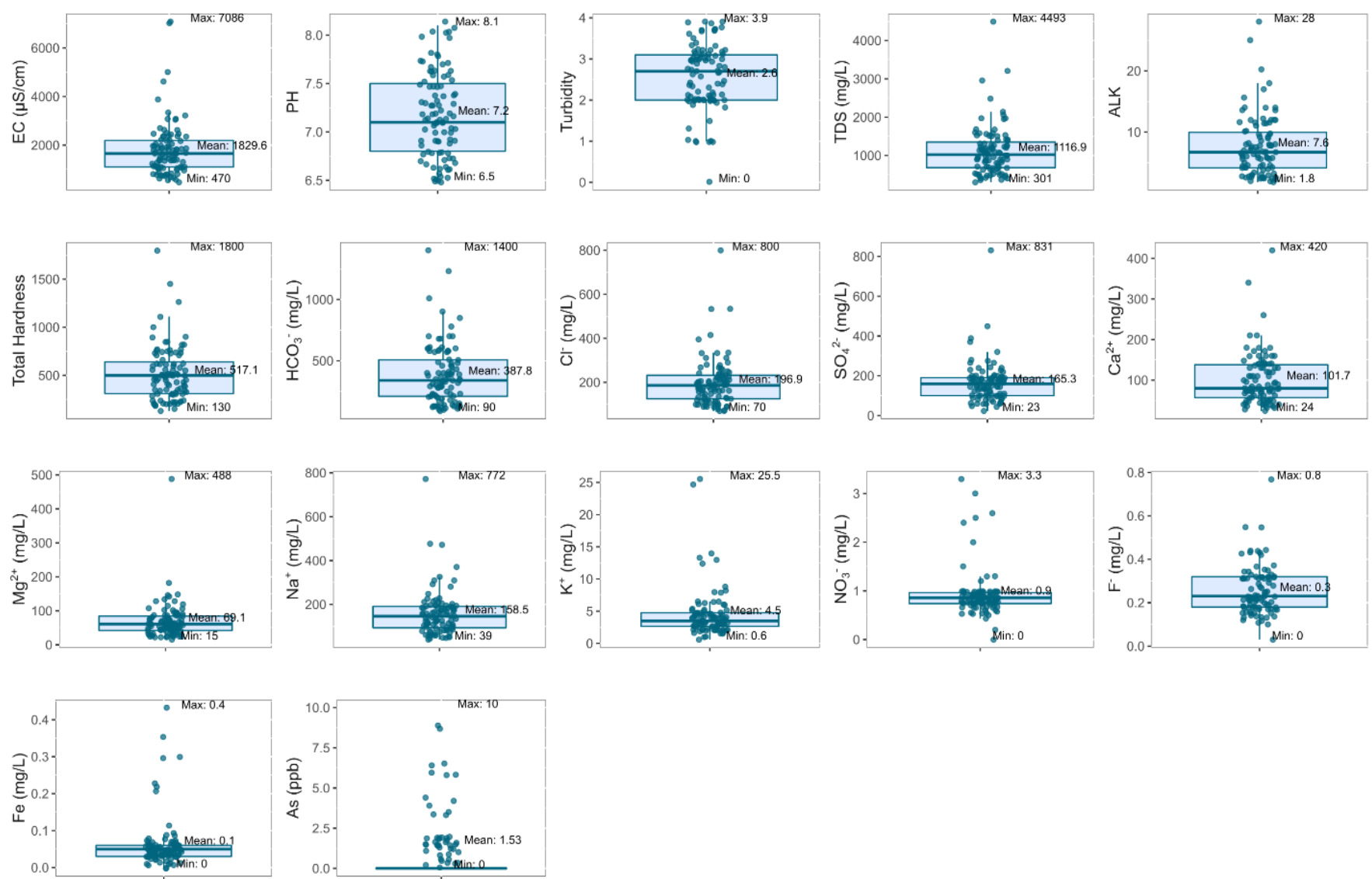

Figure 2. Box diagram of physicochemical parameters.

Hence the 17 parameters were being observed for about ninety-five samples, EC ranged from a minimum of about 470 to a maximum value of 7086, with a mean value of 1829.57, which falls beyond of WHO's recommended range. The results showing an increase in EC may be due to the dissolution of minerals present in groundwater; this dissolution may be through water-rock interaction [48]. 
The $\mathrm{pH}$ ranged from 6.5 to 8.1 , with a mean of 7.17 , indicating that the groundwater is neutral to slightly alkaline. Turbidity values are within the range determined by WHO standard. This indicates that the wells are well built and not so shallow [49]. TDS consists of calcium, bicarbonates, chlorides, magnesium, sulfates, and potassium, which are inorganic salts dissolved in groundwater [50]. Hardness is a general result of the addition of polyvalent ions, more specifically calcium and magnesium ions. The concentration of anions can be written as $\mathrm{HCO}_{3}{ }^{-}>\mathrm{Cl}^{-}>\mathrm{SO}_{4}{ }^{2-}>\mathrm{NO}_{3}{ }^{-}>\mathrm{F}^{-}$. Similarly, the concentrations of the cation are in the order $\mathrm{Na}^{+}>\mathrm{Ca}^{2+}>\mathrm{Mg}^{2+}>\mathrm{K}^{+}$. Groundwater classification based on TDS and EC is shown in Table 4.

Table 4. Classification of groundwater based on TDS and EC.

\begin{tabular}{cccc}
\hline Parameters & Range & Water Quality & Number of Samples \\
\hline & $<250$ & Excellent & - \\
Electrical & $250-750$ & Good & 3 \\
Conductivity $(\mathrm{EC})$ & $750-2000$ & Permissible & 64 \\
$(\mu \mathrm{S} / \mathrm{cm})$ & $2000-3000$ & Doubtful & 18 \\
& $>5000$ & Very hazardous & 10 \\
\hline & $<500$ & Desirable for drinking & 12 \\
TDS $(\mathrm{mg} / \mathrm{L})$ & $500-1000$ & Acceptable for & 34 \\
& $1000-3000$ & drinking & 47 \\
& $>3000$ & Suitable for irrigation & 2 \\
\hline
\end{tabular}

Thus, by analysis of groundwater based on TDS and EC, the following results were observed. According to EC ( $\mu \mathrm{S} / \mathrm{cm})$, from 95 samples studied, no any sample found to be excellent, however $3 \%$ samples found in good, $67 \%$ of samples were permissible, $19 \%$ of samples were not suitable for usage or may be harmful and $11 \%$ of the samples were toxic and hazardous for consumption. Similarly, based on TDS (mg/L), about $13 \%$ of samples were most appropriate for drinking, $36 \%$ of samples were permissible to drink, about $49 \%$ of samples were useful for irrigation, and $2 \%$ were not suitable for use in either drinking or irrigation.

\subsection{Hydrogeochemical Facies}

The Piper plot shows water chemistry and investigates groundwater hydrogeochemical composition. The different combinations of ions show the samples' dominant water chemistry under observation [51]. The diamond graph is distributed into 6 regions, as shown in Figure 3, and resulted in the majority of the samples (about 60\%) lying in the 5th region of the graph, which is a mixture of calcium, magnesium, and chloride ions $\left(\mathrm{Ca}^{2+}-\mathrm{Mg}^{2+}-\mathrm{Cl}^{-}\right.$type). About $30 \%$ of the samples showed the dominant $\mathrm{Na}^{+}-\mathrm{Cl}^{-}$type and about $10 \%$ of the samples showed chemistry of the $\mathrm{Ca}^{2+}-\mathrm{HCO}_{3}^{-}$type. One sample was in the $\mathrm{Ca}^{2+}-\mathrm{Cl}^{-}$type region. Most of the anions and cations showed no dominant types, but some samples in the cations showed dominance in $\mathrm{Na}^{+}-\mathrm{K}^{+}$type and anions, and some samples showed observant chemistry of the types $\mathrm{HCO}_{3}{ }^{-}$and $\mathrm{Cl}^{-}$; however, no points fell in zone A. The study revealed the area affected by ion exchange and weathering of silicate. The groundwater samples, implying that weathering of carbonate minerals is an influencing factor for groundwater hydrogeochemical composition. 


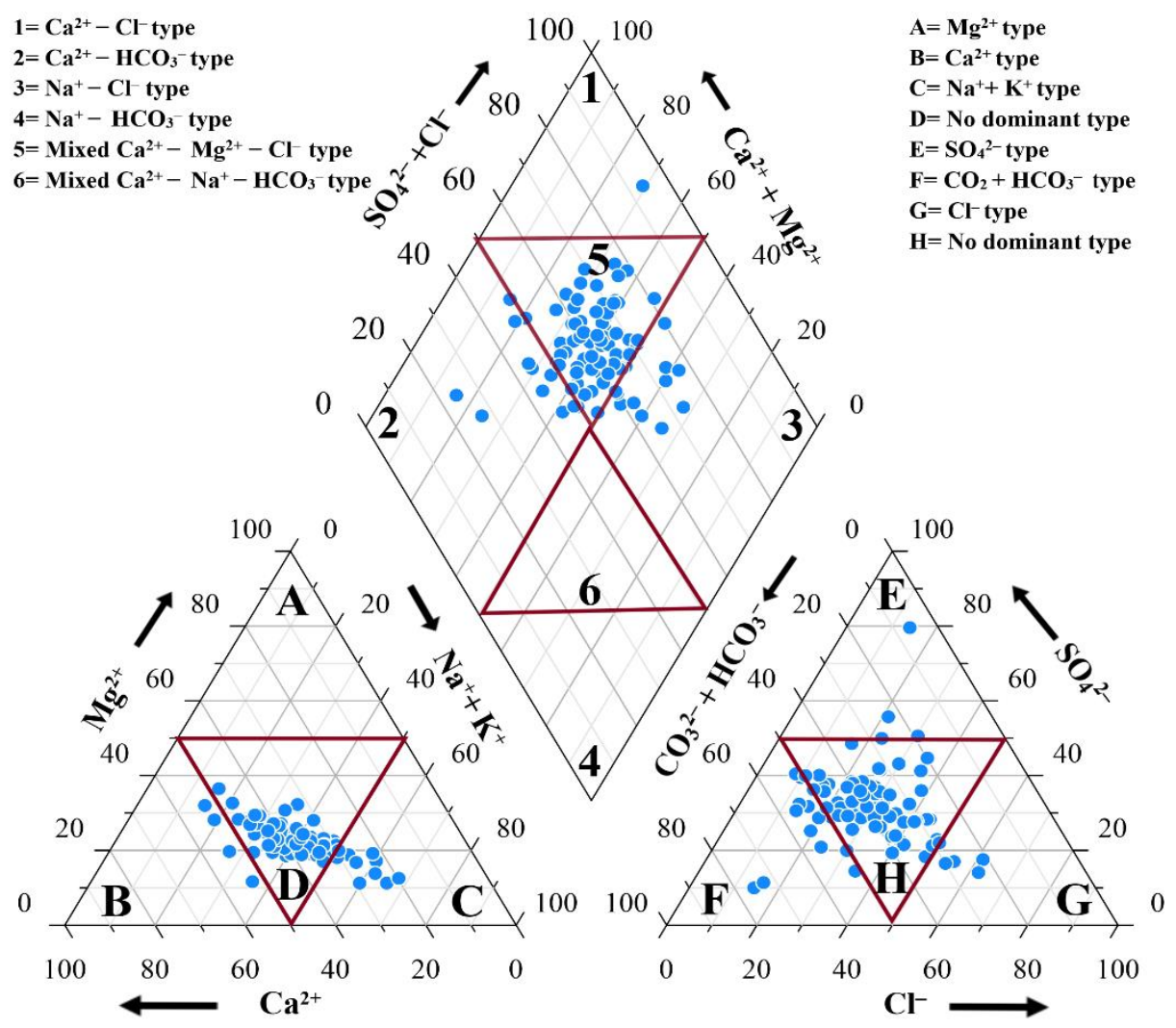

Figure 3. Piper plot for the classification of groundwater facies.

\subsection{Hydrogeochemical Evolutional Processes}

\subsubsection{Formation Mechanism of Groundwater Chemistry}

The major geochemical process used to control the hydrogeochemical characteristics of groundwater in an aquifer is represented by the Gibbs diagram. It is an efficient tool that Gibbs, in 1970, proposed for understanding the mechanism of aquifer chemistry. A Gibbs diagram demonstrates the ionic composition of samples of groundwater; the y-axis contains TDS values, and the $x$-axis has $\mathrm{Na}^{+} /\left(\mathrm{Ca}^{2+}+\mathrm{Na}^{+}\right)$and $\mathrm{Cl}^{-} /\left(\mathrm{HCO}_{3}{ }^{-}+\mathrm{Cl}^{-}\right)$respectively. Microsoft Excel 2019 was used to draw the Gibbs diagram for determining and analyzing the relationship between lithology and hydrochemistry in aquifers.

Rock dominance, precipitation dominance, and evaporation dominance are associated with groundwater characteristics [52]. The Gibbs diagram is shown in Figure 4 and indicates that rock dominance impacted most groundwater samples. Rock dominance is the erosion, transportation, and weather to the groundwater table from the parent rock. Dissolvable salts and minerals become absorbed and assimilated into groundwater. The Gibbs plot also shows the falling of some samples in the evaporation dominance zone; thus, the intense and strong evaporation in the alluvial plain is due to the shallow groundwater depth. Shallow and deep water depths are typically the reasons for evaporation dominance [53]. 

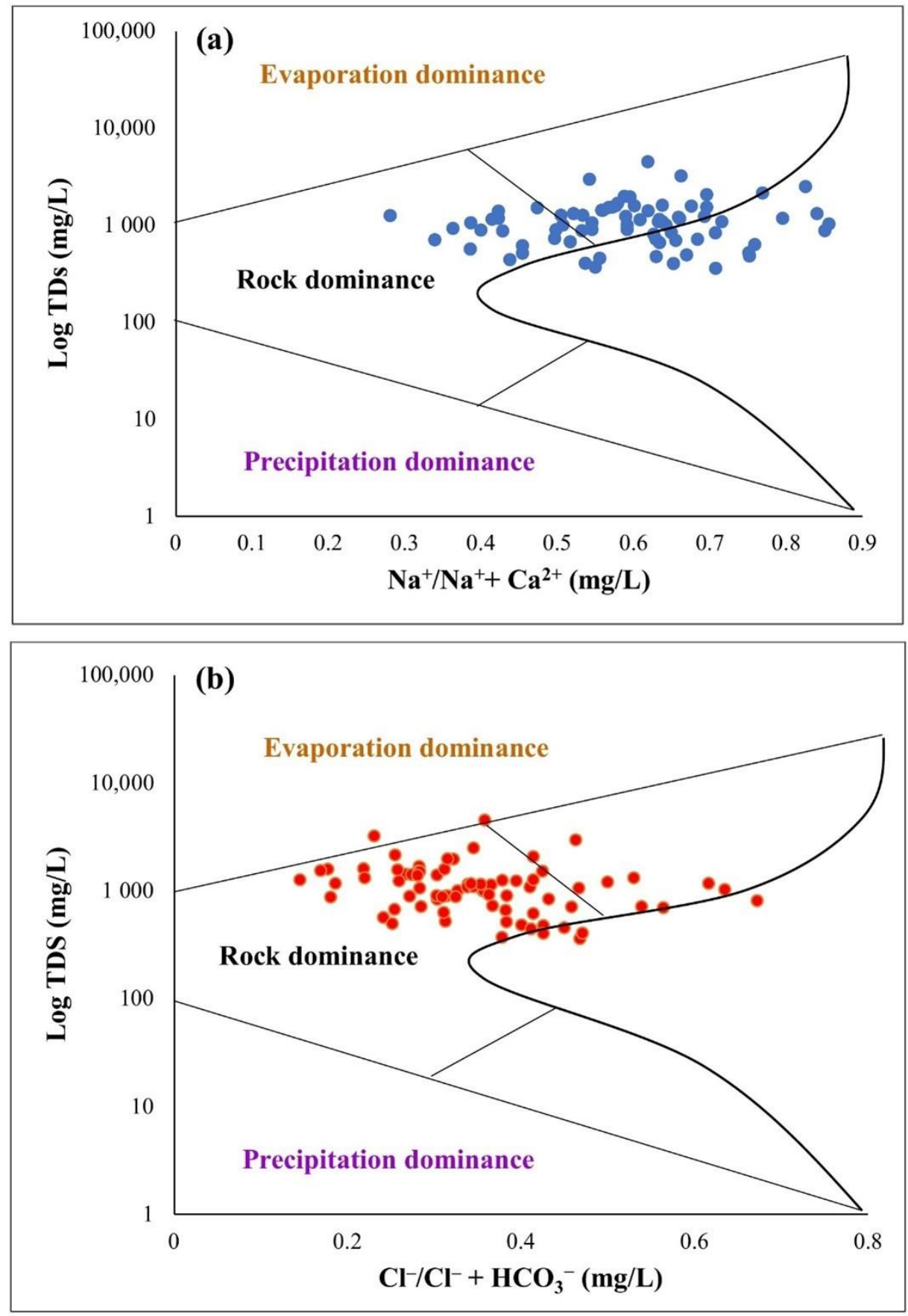

Figure 4. Gibb's plot showing the ionic composition of the samples of groundwater. (a) $\mathrm{Na}^{+} / \mathrm{Na}^{+}+$ $\mathrm{Ca}^{2+}(\mathrm{mg} / \mathrm{L})$ versus $\mathrm{Log}$ TDS $(\mathrm{mg} / \mathrm{L})$ and $(\mathbf{b}) \mathrm{Cl}^{-} / \mathrm{Cl}^{-}+\mathrm{HCO}_{3}{ }^{-}(\mathrm{mg} / \mathrm{L})$ verses $\mathrm{Log}$ TDS $(\mathrm{mg} / \mathrm{L})$.

\subsubsection{Silicate Weathering}

Silicate weathering is also important for influencing groundwater ion chemistry $[38,54]$. Source analysis of major ions in groundwater was conducted using ion-ratio maps (Figure 5). It contributes a lot to major ion chemistry and degradation of silicates, and its incongruence makes it difficult to quantify. This yields dissolved species with various other solid phases, mostly clays. Silicate weathering produces sodium by dissolution of halite Equation (13) and Equation (14), the most abundant cation in the study region is sodium. Figure 5a shows a graph between sodium and calcium. In reverse ion exchange, sodium ions are being reduced while forward ion-exchange sodium ions are added to the water [55]. Figure $5 \mathrm{~b}$ is a graph between $\mathrm{Na}^{+} / \mathrm{Cl}^{-}$(meq/L), and EC values indicate 
that the ratio of $\mathrm{Na}^{+} / \mathrm{Cl}^{-}$, which is greater than 1 , means that silicate weathering was the procedure for the derivation of $\mathrm{Na}+$ ions. As shown in Figure $5 \mathrm{~b}$, almost $90 \%$ of the sample has a $\mathrm{Na}^{+} / \mathrm{Cl}^{-}$ratio greater than 1 , which shows the production of $\mathrm{Na}^{+}$ions in water due to forward ion-exchange occurrence. It is a predominant factor that the forward ion exchange sodium ions are released in water, which further testifies that the cations are present in order $\mathrm{Na}^{+}>\mathrm{Ca}^{2+}>\mathrm{Mg}^{2+}>\mathrm{K}^{+}$. Figure $5 \mathrm{c}$ is a scatter plot between calcium and bicarbonate in $\mathrm{mg} / \mathrm{L}$. The $\mathrm{Ca}^{2+}$ and $\mathrm{HCO}_{3}{ }^{-}$scatter plot was used to investigate the dissolution of carbonate minerals; the results reveal that carbonic acid (Silicate) weathering, rather than calcite dissolution, plays a substantial role in releasing the second main cation calcium into the water. Similarly, Figure 5d shows a scatter plot between calcium and sulfate ions. Anhydrite or gypsum dissolution is common, which indicates a relatively higher concentration of sulfate $[56,57]$.

$$
\begin{gathered}
\mathrm{Na}+\mathrm{Cl} \rightarrow \mathrm{Na}^{+}+\mathrm{Cl}^{-} \\
2 \mathrm{NaAlSi}_{3} \mathrm{O}_{8}+2 \mathrm{CO}_{2}+11 \mathrm{H}_{2} \mathrm{O} \rightarrow \mathrm{Al}_{2} \mathrm{Si}_{2} \mathrm{O}_{5}(\mathrm{OH})_{4}+4 \mathrm{H}_{4} \mathrm{SiO}_{4}+2 \mathrm{Na}^{+}+2 \mathrm{HCO}_{3}^{-}
\end{gathered}
$$

(a)

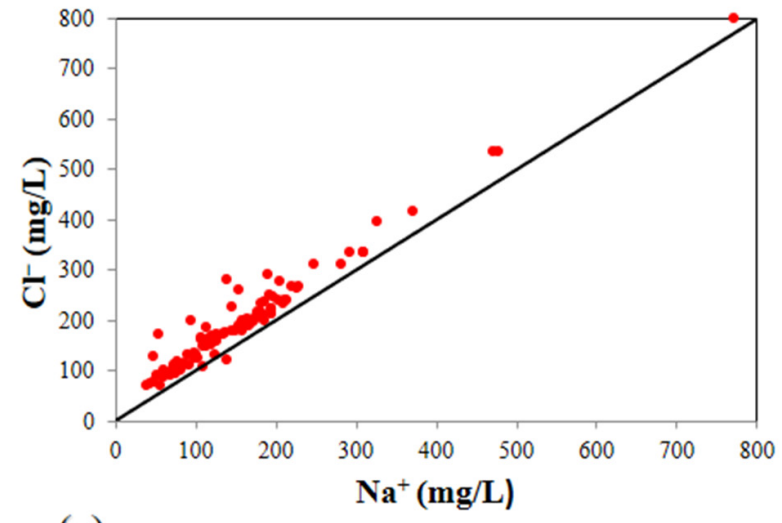

(c)

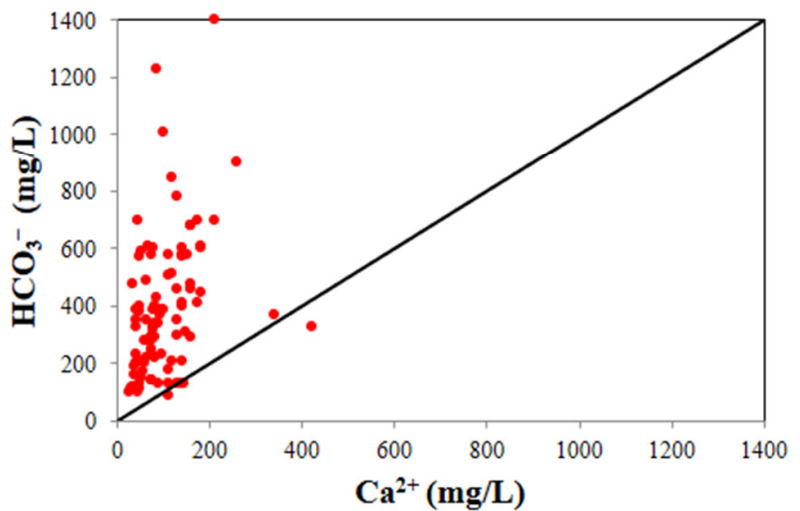

(b)

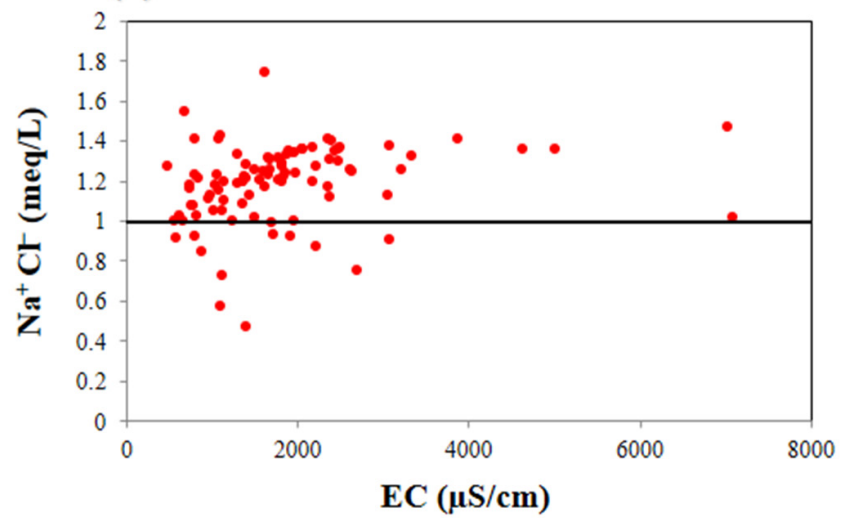

(d)

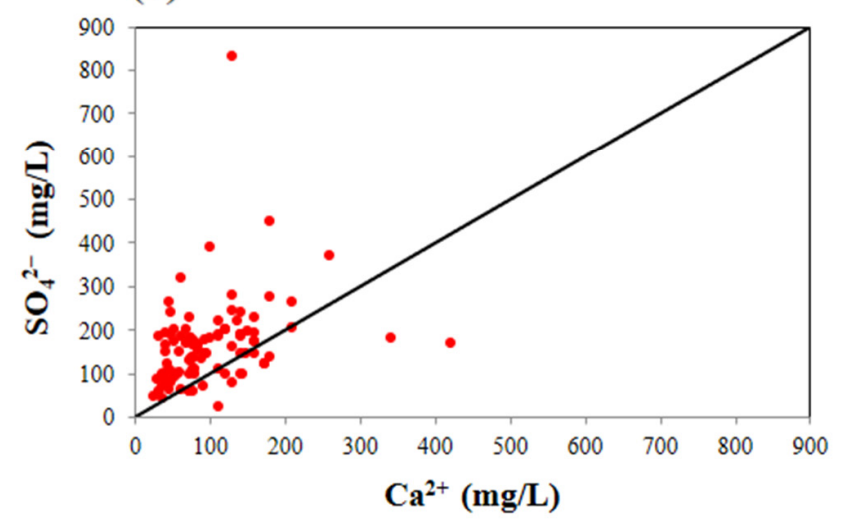

Figure 5. Scatter plot between (a) $\mathrm{Na}^{+}$and $\mathrm{Cl}^{-}(\mathrm{mg} / \mathrm{L}),(\mathbf{b}) \mathrm{EC}(\mu \mathrm{S} / \mathrm{cm})$ and $\mathrm{Na}^{+} \mathrm{Cl}^{-}(\mathrm{meq} / \mathrm{L}),(\mathbf{c}) \mathrm{Ca}^{2+}$ and $\mathrm{HCO}_{3}{ }^{-}(\mathrm{mg} / \mathrm{L})$, (d) $\mathrm{Ca}^{2+}$ and $\mathrm{SO}_{4}{ }^{2-}(\mathrm{mg} / \mathrm{L})$.

Furthermore, Figure 6a indicates that the major $\mathrm{Na}^{+}$ions in water are released by the forward ion-exchange method. Similarly, Figure $6 \mathrm{~b}$ indicates that silicate weathering rather than carbonate mineral dissolution was used to release calcium and magnesium ions. 
(a)

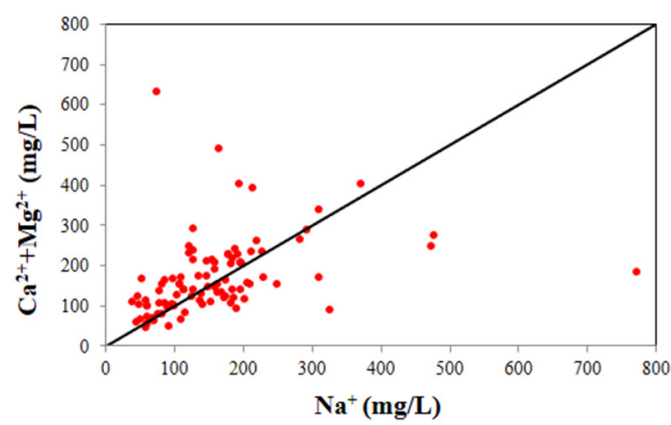

(b)

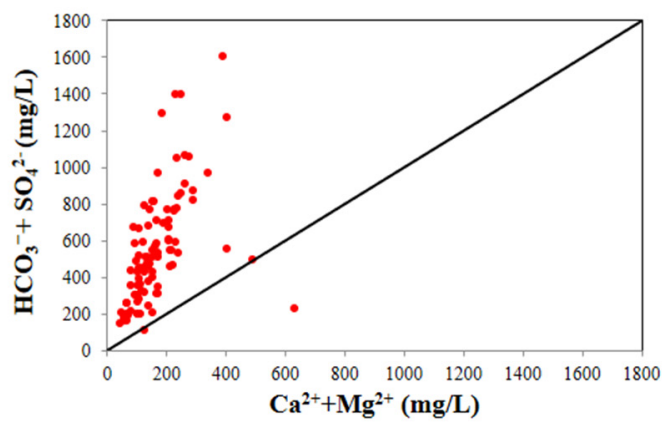

Figure 6. Scatter plot between $(\mathbf{a}) \mathrm{Na}^{+}$and $\mathrm{Ca}^{2+}+\mathrm{Mg}^{2+}(\mathrm{mg} / \mathrm{L})$ and $(\mathbf{b}) \mathrm{Ca}^{2+}+\mathrm{Mg}^{2+}(\mathrm{mg} / \mathrm{L})$ and $\mathrm{HCO}_{3}{ }^{-}+\mathrm{SO}_{4}{ }^{2-}(\mathrm{mg} / \mathrm{L})$.

\subsection{Major Ion Sources and Hydrogeochemical Evolution}

\subsubsection{Ion Exchange}

To investigate and characterize the source of ions in water samples, chloro-alkaline indices (CAI) were used. The exchange of $\mathrm{Na}^{+}$and $\mathrm{K}^{+}$from water with $\mathrm{Mg}^{2+}$ and $\mathrm{Ca}^{2+}$ indicated the CAI is positive and, similarly, the exchange of magnesium and calcium from the water with sodium and potassium is indicated by the negative CAI [58]. The positive CAI-1 and CAI-2 are known as direct or reverse ion exchange and the negative indices show indirect or forward ion exchange [59]. In the given samples, CAI-1 and CAI-2 indices were calculated, and most of the indices were negative, as shown in the Figure 7 . This indicates forward ion exchange. The formulae are given as in Equation (15) and Equation (16).

$$
\begin{gathered}
\mathrm{CAI}-1=\frac{\mathrm{Cl}^{-}-\left(\mathrm{Na}^{+}+\mathrm{K}^{+}\right)}{\mathrm{Cl}^{-}} \\
\mathrm{CAI}-2=\frac{\mathrm{Cl}^{-}-\left(\mathrm{Na}^{+}+\mathrm{K}^{+}\right)}{\mathrm{SO}_{4}^{-2}+\mathrm{HCO}_{3}^{-}+\mathrm{CO}_{3}^{-2}+\mathrm{NO}_{3}^{-}}
\end{gathered}
$$
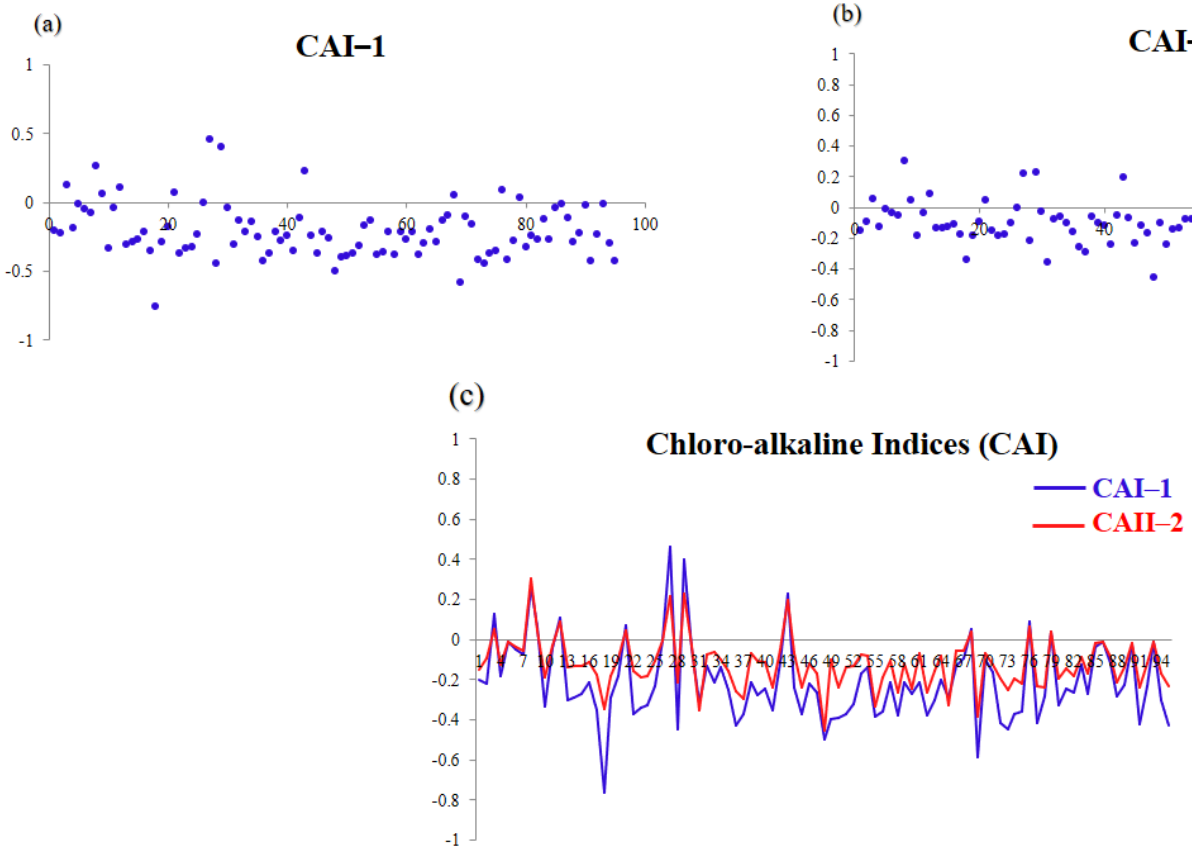

- CAI-1

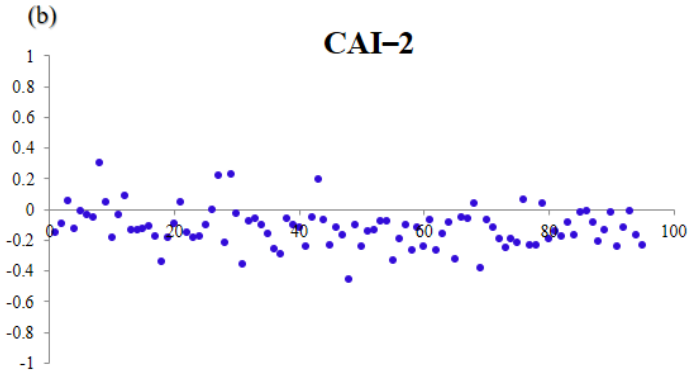




\subsubsection{Correlation Analysis}

Pearson correlation is a useful method for expressing the relationship between several hydrogeochemical and physiochemical characteristics in groundwater. A coefficient of correlation matrix of 17 parameters and samples $(n=95)$ was calculated using IBM SPSS Statistic 20. The parameters were analyzed the samples showing $r>0.5$ were considered to be positive with moderate correlation while $r>0.9$ represented strong positive correlation. The 2-tailed Pearson correlation test was carried out to find the significance level.

According to the Pearson correlation coefficient matrix (Table 5), the EC was positively correlated with $\mathrm{TH}, \mathrm{Cl}^{-}, \mathrm{SO}_{4}{ }^{2-}, \mathrm{Na}^{+}, \mathrm{NO}_{3}{ }^{-}, \mathrm{F}(\mathrm{r}>0.5)$. This suggests that the salinity of groundwater is influenced by the key components and that the trends among them follow a similar pattern. Similarly, there was a strong correlation of TH with $\mathrm{Cl}^{-}, \mathrm{SO}_{4}{ }^{2-}, \mathrm{Na}^{+}$ $(\mathrm{r}>0.9)$ and a moderate correlation with, $\mathrm{K}^{+}, \mathrm{NO}_{3}{ }^{-}, \mathrm{F}, \mathrm{Fe}(\mathrm{r}>0.5)$. However, $\mathrm{HCO}_{3}{ }^{-}$ correlation exists with $\mathrm{Cl}^{-}$and $\mathrm{Na}^{+}(\mathrm{r}=0.52)$, which demonstrates $\mathrm{Na}^{+}$origin from silicate weathering [53]. The main exchangeable ions, $\mathrm{Na}^{+}, \mathrm{K}^{+}, \mathrm{Ca}^{+}$and $\mathrm{Na}^{+}, \mathrm{K}^{+}, \mathrm{Mg}^{+}$, were also found to have a positive correlation. As a result, the simultaneous rise or reduction in cations is mostly due to dissolution/precipitation reactions and concentration effects. The very strong correlation of $\mathrm{Cl}^{-}$with $\mathrm{SO}_{4}{ }^{2-}, \mathrm{Na}^{+}$, and $\mathrm{SO}_{4}{ }^{2-}$ with $\mathrm{Na}^{+}(\mathrm{r}>0.9)$ indicates that high salinity occurs in the area as a result of excessive fertilizer use and salt leaching from irrigation water return flow. It is also possible that the sulfate deposition in aquifer water was caused by fertilizer application and organic matter degradation. However, there is no statistically significant association between $\mathrm{pH}$ with the other factors in the region. These connections represented the ions' major contributions to groundwater totals and revealed significant effects.

\subsubsection{Multivariate Analysis}

Multivariate statistical approaches have been extensively employed to help solve environmental issues and comprehend natural and human processes [37,60]. In order to pull relevant information from water-quality data, correlation analysis, principal component analysis, and hierarchical cluster analysis have been widely employed. Multivariate statistical methods have been widely used to understand mechanism of environmental issues and comprehend natural and anthropogenic processes, thus principal component analysis (PCA) and hierarchical cluster analysis (HCA) have been widely used to investigate the mechanism of hydro-geochemistry.

Principal component analysis (PCA) was performed on the groundwater dataset for additional statistical validation (Table 6). A PCA plot is a powerful recognition method that represents sample characteristics and parameter distribution, as well as the source of contamination $[25,60]$. All four components explain $65.74 \%$ of the total cumulative variance. The variations described related to the chemical parameter loadings are categorized as strong, $(>0.75)$, moderate ( 0.75 to 0.50$)$, and weak ( 0.50 to 0.30$)$. PCA with Varimax normalization was used to study the intercorrelation of physicochemical properties. The PCA resulted of four components, each with its own variance and eigenvalues; i.e., $42.67 \%$ and $7.25 \%$ for factor $1,8.25 \%$, and $1.4 \%$ for factor $2,7.56 \%$ and $1.29 \%$ for factor 3 , and $7.26 \%$ and 1.23 for factor 4 , respectively.

The first factor, $\mathrm{F} 1$, explained $42.67 \%$ of the total variance and exhibited significant positive EC and total hardness $\mathrm{HCO}_{3}{ }^{-}, \mathrm{Cl}^{-}, \mathrm{Na}^{+}$, which showed anthropogenic contamination sources from industrial effluents such as $\mathrm{Cl}^{-}, \mathrm{Na}^{+}, \mathrm{SO}_{4}{ }^{2-}, \mathrm{K}^{+}, \mathrm{NO}_{3}{ }^{-}$and other parameters. Thus, agricultural activities are indicated as a contributing process and may be obtained by gypsum and calcium-bearing minerals dissolution [61]. The sources of $\mathrm{NO}_{3}{ }^{-}$ include onsite sanitation, municipal waste, and nutrient pollution caused by surrounding agricultural activities that have been going on for a long time [62]. Gypsum and calciumrich minerals, perhaps the main sources of $\mathrm{Ca}^{2+}, \mathrm{SO}_{4}{ }^{2-}$, and $\mathrm{HCO}_{3}{ }^{-}$, are dissolving into the water [63]. 
Table 5. Matrix of correlation coefficients for groundwater physiochemical parameters.

\begin{tabular}{|c|c|c|c|c|c|c|c|c|c|c|c|c|c|c|c|c|c|}
\hline Parameters & EC & PH & TURB & TDS & ALK & TH & $\mathrm{HCO}_{3}{ }^{-}$ & $\mathrm{Cl}^{-}$ & $\mathrm{SO}_{4}^{2-}$ & $\mathrm{Ca}^{2+}$ & $\mathrm{Mg}^{2+}$ & $\mathrm{Na}^{+}$ & $\mathrm{K}^{+}$ & $\mathrm{NO}_{3}^{-}$ & $\mathrm{F}^{-}$ & $\mathrm{Fe}$ & As \\
\hline EC & 1 & & & & & & & & & & & & & & & & \\
\hline PH & -0.20 & 1 & & & & & & & & & & & & & & & \\
\hline TURB & 0.03 & 0.14 & 1 & & & & & & & & & & & & & & \\
\hline ALK & 0.20 * & -0.17 & -0.02 & 0.04 & 1 & & & & & & & & & & & & \\
\hline TH & $0.62 * *$ & $-0.26^{* *}$ & 0.04 & $0.37^{* *}$ & 0.32 ** & 1 & & & & & & & & & & & \\
\hline $\mathrm{HCO}_{3}{ }^{-}$ & $0.25 *$ & $-0.21 *$ & 0.11 & $0.40^{* *}$ & 0.19 & $0.62^{* *}$ & 1 & & & & & & & & & & \\
\hline $\mathrm{Cl}^{-}$ & $0.61^{* *}$ & $-0.25 *$ & 0.04 & $0.33^{* *}$ & 0.25 * & 0.94 ** & $0.52 * *$ & 1 & & & & & & & & & \\
\hline $\mathrm{Ca}^{2+}$ & $0.36 * *$ & -0.12 & -0.12 & 0.24 * & $0.34^{* *}$ & $0.41^{* *}$ & $0.35 * *$ & $0.29^{* *}$ & $0.29 * *$ & 1 & & & & & & & \\
\hline $\mathrm{Mg}^{2+}$ & 0.06 & -0.01 & -0.03 & 0.20 * & 0.01 & 0.30 ** & $0.46^{* *}$ & $0.25 *$ & $0.23 *$ & $0.28^{* *}$ & 1 & & & & & & \\
\hline $\mathrm{Na}^{+}$ & $0.62 * *$ & $-0.23 *$ & 0.04 & $0.31^{* *}$ & $0.29^{* *}$ & $0.93^{* *}$ & $0.52 * *$ & $0.97^{* *}$ & $0.96 * *$ & $0.31^{* *}$ & $0.24 *$ & 1 & & & & & \\
\hline $\mathbf{K}^{+}$ & $-0.5^{* *}$ & $-0.26^{* *}$ & 0.04 & $0.38^{* *}$ & $0.25 *$ & $0.64 * *$ & $0.40^{* *}$ & $0.61^{* *}$ & $0.63 * *$ & $0.31^{* *}$ & 0.18 & $0.61 * *$ & 1 & & & & \\
\hline $\mathrm{NO}_{3}^{-}$ & $0.58^{* *}$ & -0.17 & 0.07 & 0.23 * & 0.23 * & 0.63 ** & $0.27^{* *}$ & 0.63 ** & $0.67 * *$ & $0.34^{* *}$ & 0.12 & $0.63 * *$ & $0.50 * *$ & 1 & & & \\
\hline F & $0.52 * *$ & $-0.26^{* *}$ & 0.12 & 0.23 * & $0.39^{* *}$ & $0.66^{* *}$ & $0.32 * *$ & $0.65 * *$ & $0.68 * *$ & $0.29^{* *}$ & 0.08 & $0.67 * *$ & $0.55 * *$ & $0.54 * *$ & 1 & & \\
\hline $\mathrm{Fe}$ & $0.41^{* *}$ & -0.11 & 0.01 & $0.29^{* *}$ & $0.22 *$ & $0.58^{* *}$ & $0.39 * *$ & $0.57^{* *}$ & $0.56 * *$ & 0.20 * & 0.16 & $0.58 * *$ & $0.62 * *$ & $0.384^{* *}$ & $0.43 * *$ & 1 & \\
\hline As & -0.06 & -0.07 & 0.15 & 0.06 & 0.10 & 0.05 & 0.02 & -0.04 & -0.004 & -0.06 & 0.0004 & -0.08 & -0.02 & -0.04 & 0.16 & -0.09 & 1 \\
\hline
\end{tabular}

*. Correlation is significant at the 0.05 level (2-tailed). ${ }^{* *}$. Correlation is significant at the 0.01 level (2-tailed). 
Table 6. Rotated factor loadings for the groundwater samples in the study area.

\begin{tabular}{ccccc}
\hline Parameter & F.1 & F.2 & F.3 & F.4 \\
\hline EC & $\mathbf{0 . 7 1}$ & -0.27 & -0.15 & 0.06 \\
PH & -0.32 & 0.07 & 0.07 & 0.51 \\
Turbidity & 0.06 & -0.1 & 0.74 & 0.32 \\
TDS & 0.44 & 0.4 & 0.27 & 0.02 \\
$\mathrm{ALK}$ & 0.39 & -0.16 & -0.02 & -0.61 \\
Total Hardness & $\mathbf{0 . 9 5}$ & 0.03 & 0.03 & 0.04 \\
$\mathrm{HCO}_{3}^{-}$ & $\mathbf{0 . 6 2}$ & $\mathbf{0 . 5 5}$ & 0.16 & -0.03 \\
$\mathrm{Cl}^{-}$ & $\mathbf{0 . 9 3}$ & -0.07 & -0.02 & 0.17 \\
$\mathrm{SO}_{4}^{2-}$ & $\mathbf{0 . 9 3}$ & -0.13 & 0.01 & 0.14 \\
$\mathrm{Ca}^{2+}$ & 0.47 & 0.32 & -0.27 & -0.39 \\
$\mathrm{Mg}^{2+}$ & 0.31 & $\mathbf{0 . 7 5}$ & 0 & 0.03 \\
$\mathrm{Na}^{+}$ & $\mathbf{0 . 9 3}$ & -0.08 & -0.05 & 0.16 \\
$\mathrm{~K}^{+}$ & $\mathbf{0 . 7 6}$ & -0.03 & -0.01 & 0.02 \\
$\mathrm{NO}_{3}^{-}$ & $\mathbf{0 . 7 2}$ & -0.22 & -0.07 & 0.07 \\
$\mathrm{~F}^{-}$ & $\mathbf{0 . 7 5}$ & -0.28 & 0.17 & -0.19 \\
Fe $_{\text {As }}$ & $\mathbf{0 . 6 7}$ & 0.02 & -0.06 & 0.18 \\
Eigen value & 0 & -0.07 & 0.71 & -0.45 \\
Loading \% & 7.25 & 1.4 & 1.29 & 1.23 \\
Cumulative $\%$ & 42.67 & 8.25 & 7.56 & 7.26 \\
\hline Each PC's effective parameters are & 42.67 & 50.92 & 58.49 & 65.74 \\
\hline
\end{tabular}

Each PC's effective parameters are denoted by a bold number.

F2 describes $8.25 \%$ of the variability and significant correlation between $\mathrm{mg}^{+}$and $\mathrm{HCO}_{3}{ }^{-}$, while further variables have loadings with modest positive and negative values. The most prevalent sinks for secondary salts in soil include chemical weathering, leaching, secondary salt dissolution in pore spaces, agricultural effluents, plants, and clays. It implies that both F1 and F2 may reflect the impacts of lowering variables, hence F1 and F2 are included in the PCA score plot (Figure 8). Factor 3 and Factor 4 account for $7.5 \%$ and $7.26 \%$ respectively, of the overall variation; thus, extreme negative values suggest areas not affected by the process.

CA Cluster analysis (CA) is an important multivariate statistical technique often used to better organize complex water data into various clusters [64]. Ward's method, which often calculates the squared Euclidean distance between the water variable for the similarity index, was applied. All groundwater samples from the three clusters were assigned to the factors based on their PCA factor scores to show the relative relevance of factors in various clusters [65]. In this study $(n=95)$ of groundwater samples, 48 contained $C 1$, while 37 samples contained $\mathrm{C} 2$, and 10 samples contained in $\mathrm{C} 3$. The findings of the water study revealed that the majority of the samples were classed as Cluster-I, which reveals the hardness, $\mathrm{Na}^{+}, \mathrm{K}^{+}$and $\mathrm{HCO}_{3}{ }^{-}, \mathrm{Cl}^{-}, \mathrm{SO}_{4}{ }^{2-}, \mathrm{NO}_{3}{ }^{-}$concentration, and other chemical characteristics, showing a high sensitivity to industrial, irrigational, and overabundant agricultural activities. Cluster II was linked to the highest average $\mathrm{Mg}^{2+}$ and $\mathrm{HCO}_{3}{ }^{-}$due to the dissolution of gypsum, as well as the interaction of water and rock. The source of $\mathrm{HCO}_{3}{ }^{-}$might be from industrial waste water and sulfate fertilizer contaminating the groundwater. Various clusters' prominent characteristics are shown in Figure 9; samples are plotted in both negative and positive direction as shown by Cluster-I, which indicates that they are affected by both lithological and silicate weathering factors. Compared to Cluster-II, Cluster-III samples are more likely to be plotted in the positive direction, which indicates the dissolved minerals, including $\mathrm{Fe}^{2+}$, are released in the aquifer by dissolution due to high acidity. 
(a) Variables factor map PCA

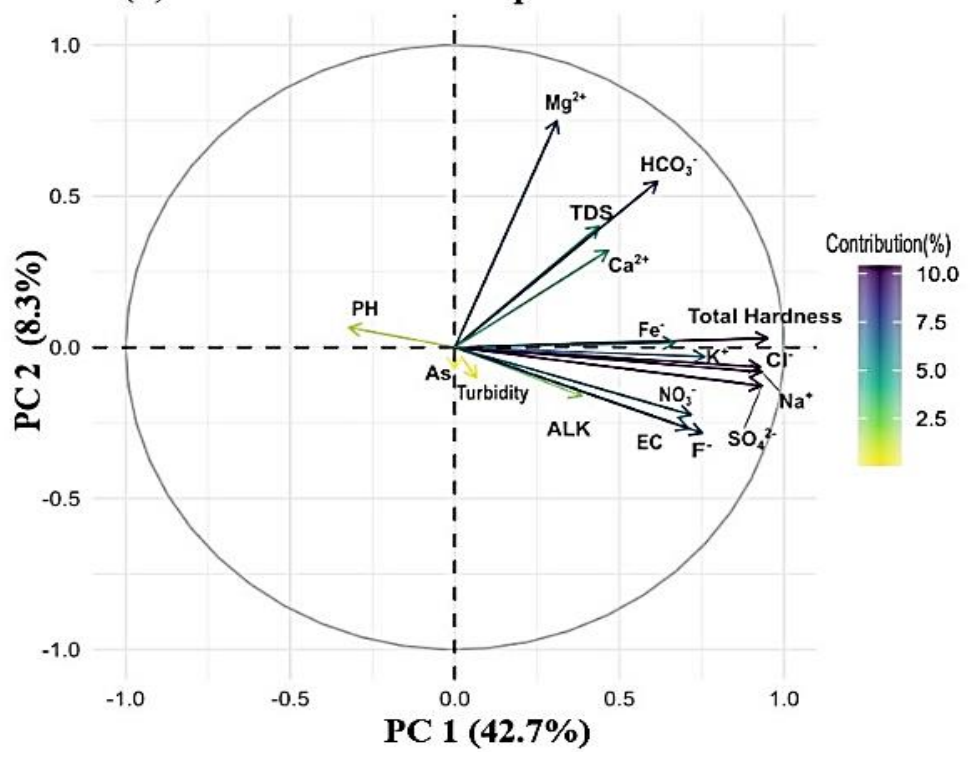

(b) Top 10 contributions of variables to $\mathrm{PC} 1$ and $\mathrm{PC} 2$

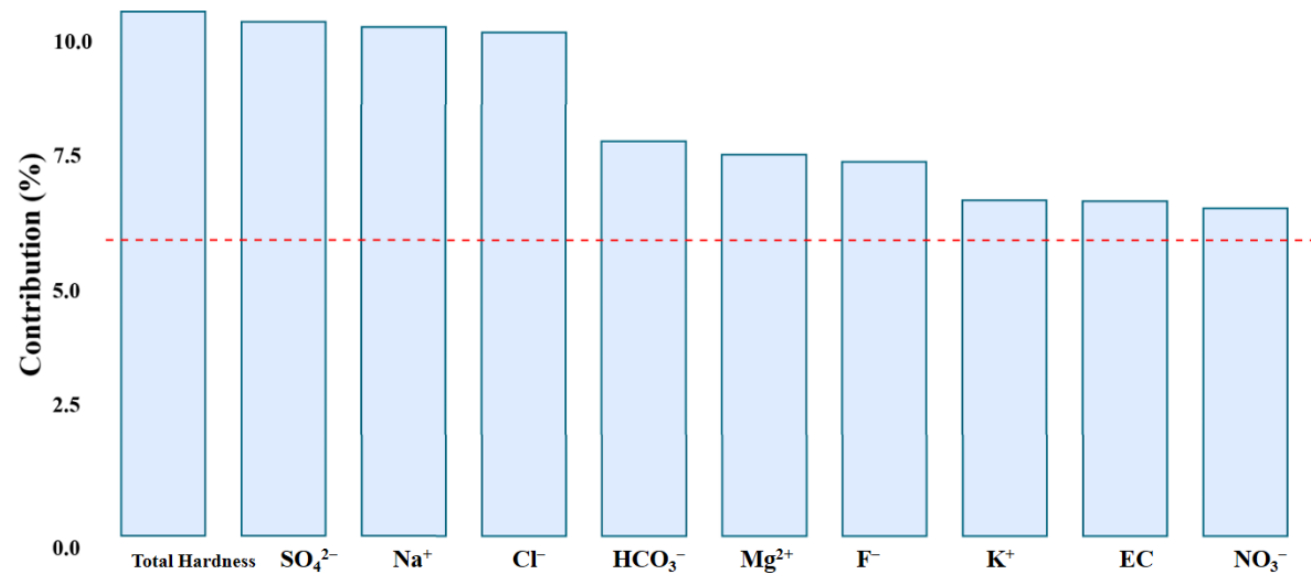

(c) Variances of Principal Components

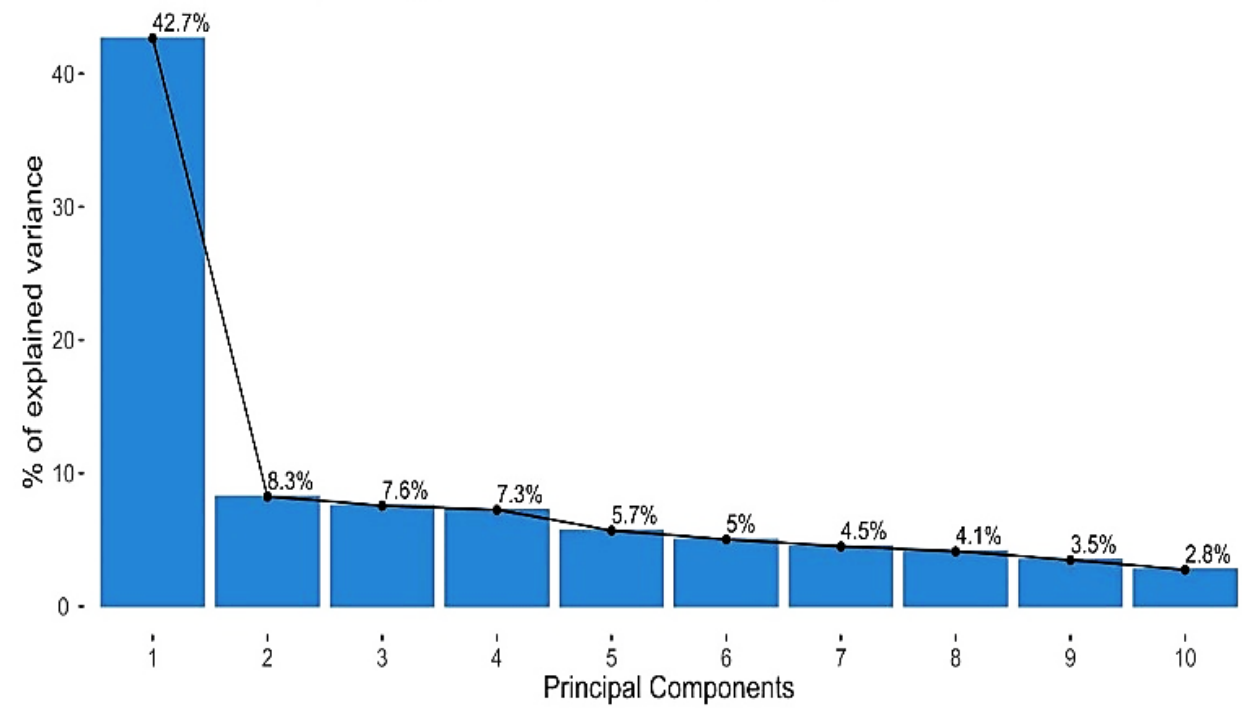

Figure 8. Analysis of principal component (a) Variable factors map PCA (b) top contribution PC1 and PC 2 (c) Variances of principal components. 

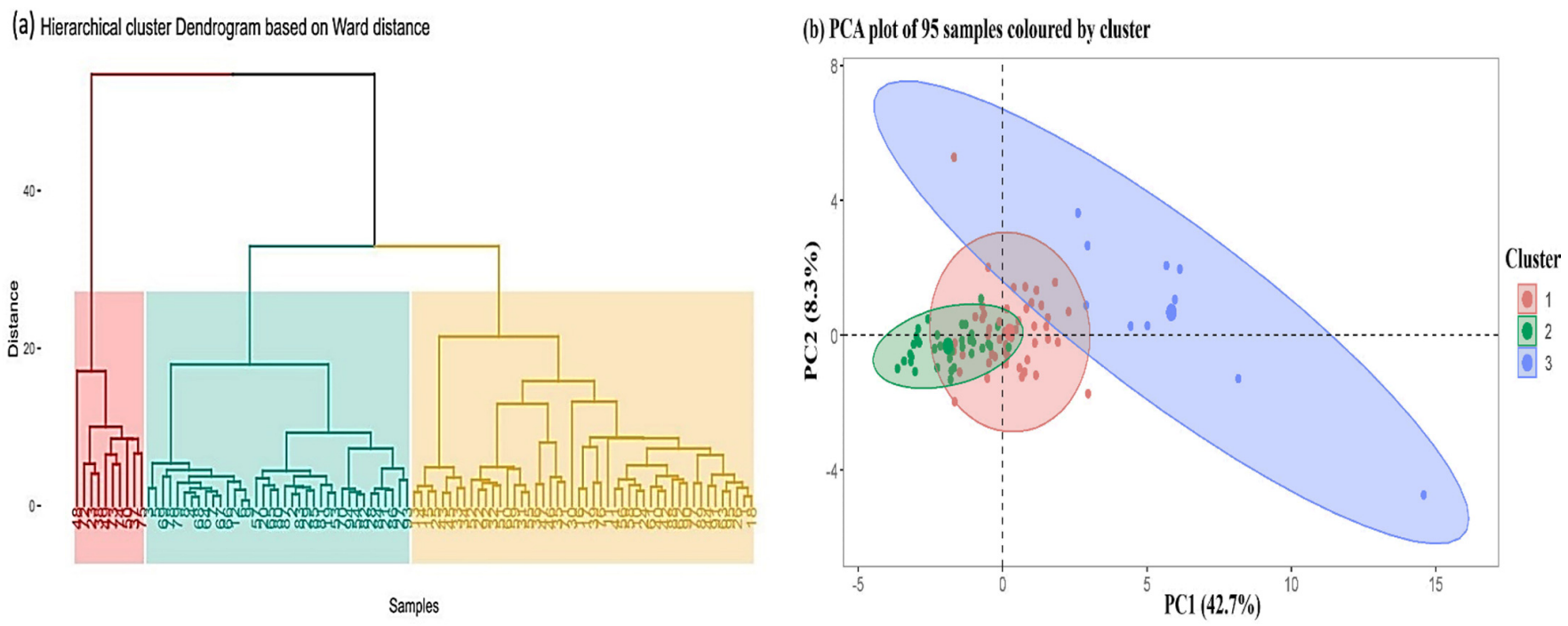

Figure 9. (a) Clustering of groundwater samples based on dissimilarity (b) Distribution of factors on samples of the three clusters.

\subsection{Groundwater Suitability Evaluation}

Groundwater suitability for drinking and other uses is determined using hydrochemical analysis data.

\subsubsection{Water Quality Assessment for Drinking Purpose}

The selected samples of water used the WQI to addressing overall groundwater quality [66]. Relative weights were calculated as shown in Table 7, where the classification of drinking water is computed. WQI values are divided into five groups: (i) excellent $<50$, (ii) good $>50$, (iii) poor $>100$, (iv) very poor $>200$, and (v) water unsuitable for drinking $>300$, as shown in Table 7 .

Table 7. Water quality index (WQI) of water samples in the study area.

\begin{tabular}{ccc}
\hline WQI Range & Quality of Water & No. of Samples \\
\hline$<50$ & Excellent & 17 \\
$>50$ & Good & 46 \\
$>100$ & Poor & 16 \\
$>200$ & Very poor & 11 \\
$>300$ & Unsuitable & 5 \\
\hline
\end{tabular}

\subsubsection{Groundwater Suitability for Irrigation Purpose}

SAR or the alkali hazard index are useful tools for determining the suitability of groundwater for irrigation. Wilcox and USSL diagrams are common indices for assessing groundwater suitability for irrigation. Sodium absorption ratio (SAR), Na \%, permeability index (PI), Magnesium Ratio (MAR), and Kelley's ratio (KR) were computed and are shown in Table 8.

Table 8. Calculated irrigation quality indices for groundwater of the study area.

\begin{tabular}{ccccc}
\hline Parameters & Minimum & Maximum & Mean & SD \\
\hline SAR & 4.16 & 80.48 & 17.98 & 10.03 \\
Na $\%$ & 10.77 & 81.25 & 48.16 & 11.31 \\
PI & 12.09 & 83.06 & 53.75 & 11.51 \\
MAR & 12 & 77.21 & 41.02 & 13.33 \\
KI & 0.11 & 96.70 & 1.99 & 0.581 \\
\hline
\end{tabular}


Higher salinity decreases osmotic activity by preventing water from reaching plant branches and leaves, resulting in lower yield. Groundwater is classified by SAR as low $($ SAR $<10)$, medium $(10<$ SAR_18), high $(18<$ SAR_26), and very high $(S A R>26)$ sodium hazard. Sodium salinity hazard is due to higher SAR values, which reduce the availability of soil water, which in turn affects crop growth and reduces the ratio of magnesium and calcium nutrients. The increased salt absorption in the research area can be linked to clay minerals and the survival of a variety of other rock types. The most likely cause of an increased sodium concentration in water is some kind of lithological source that causes the suspension of such minerals. A high quantity of sodium in water may also be caused by the use of agrochemicals in agricultural activities. High salt content in soil has disastrous effects on soil structure, infiltration, and aeration, and a higher sodium percentage may also decrease flocculation and weaken the permeability and tilth of the soil $[67,68]$.

Salinity hazards are classified as very high salinity water $\left(\mathrm{C}_{4}\right)$, high salinity water $\left(C_{3}\right)$, medium salinity water $\left(C_{2}\right)$, and low salinity water $\left(C_{1}\right)$. However alkalinity hazards are divided into four categories: very high sodium water $\left(\mathrm{S}_{4}\right)$, high sodium water $\left(\mathrm{S}_{3}\right)$, medium sodium water $\left(\mathrm{S}_{2}\right)$, and low sodium water $\left(\mathrm{S}_{1}\right)$. However, SAR was employed as an alkalinity hazard, while EC was used as a salinity hazard. Figure 10 show the USSL diagram, wherein most samples lie in the region from $C_{2} S_{2}$ to $C_{2} S_{4}$ and $C_{3} S_{2}$ to $C_{3} S_{4}$ whereas six samples lie in $\mathrm{C}_{2} \mathrm{~S}_{1}$ and three sample in $\mathrm{C}_{3} \mathrm{~S}_{1}$, which is suitable for irrigation with minimal $\mathrm{Na}^{+}$exchange [69]. However, one sample lies in $\mathrm{C}_{4} \mathrm{~S}_{2}$ and one sample $\mathrm{C}_{4} \mathrm{~S}_{3}$, four samples in $\mathrm{C}_{4} \mathrm{~S}_{4}$, and all these samples show very high salinity and medium to very high alkalinity and cannot not used for irrigation [53]. Thus, $60 \%$ fall in $C_{3}$ and $\mathrm{C}_{4}$, which show the highest salinity and medium to high sodium hazard, and cannot be used for irrigation purpose, because the water under these regions is not suitable for any agricultural activity [70]. About (40\%) of the samples lie in these regions, restricting them use in irrigation.

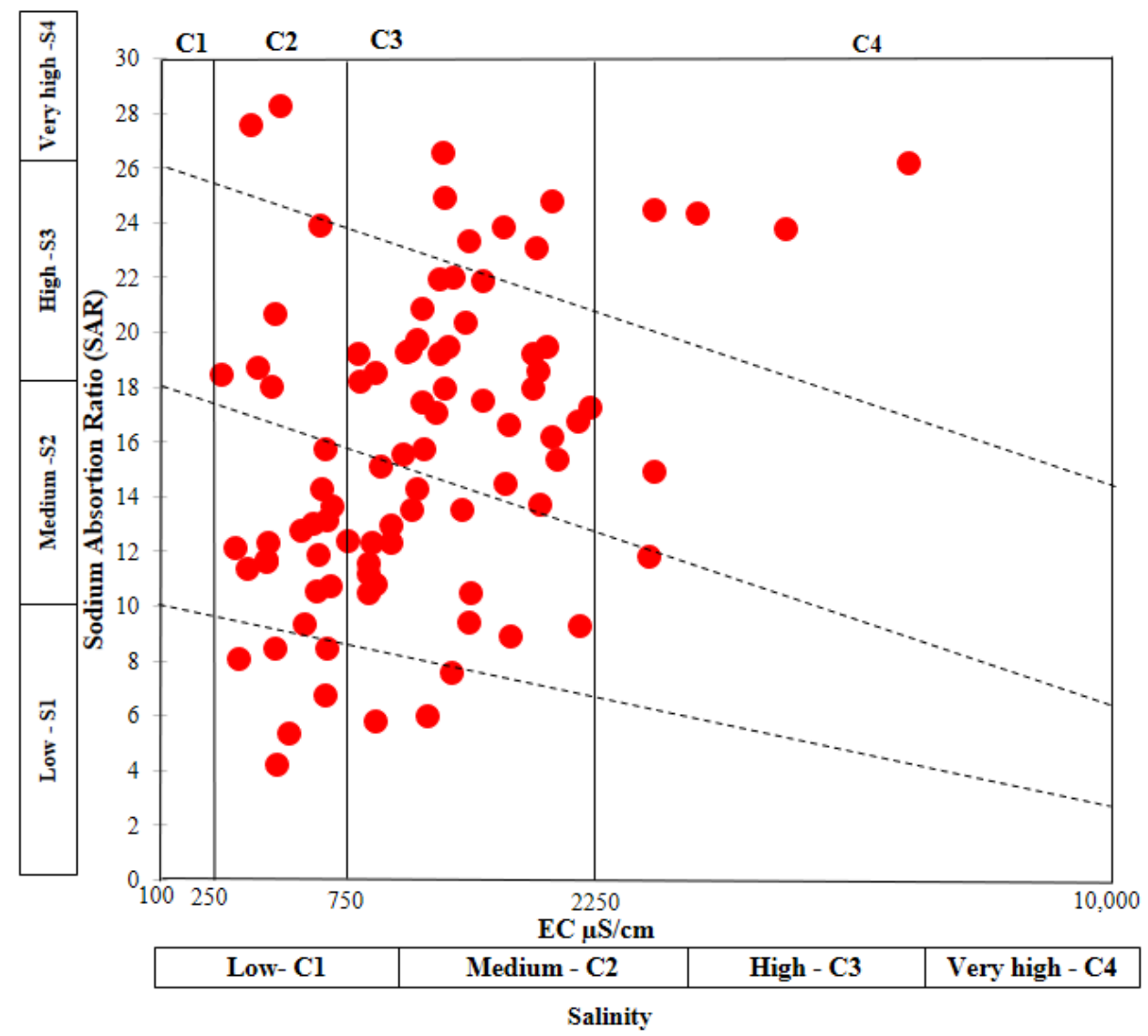

Figure 10. Irrigation water classification diagram United States Salinity Laboratory (USSL). 
The sodium percentage $(\mathrm{Na} \%)$ also indicates suitability of the water for irrigation purposes [71]. To explore the water samples for irrigation, the Wilcox diagram formed is shown in Figure 11. Different samples laid in different fields excellent to good, good to permissible, permitted to doubtful, doubtful to inappropriate, and finally unsuitable the classifications for these fields [72,73]. The Wilcox diagram observed that almost $50 \%$ of the samples are acceptable to use for irrigation, about $25 \%$ of the sample lie in permissible to doubtful region, about $20 \%$ sample lies in the doubtful to unsuitable to be used for irrigation field, and $5 \%$ samples lie in the unsuitable region, meaning they cannot be used for irrigation due to the adverse effects they may cause.

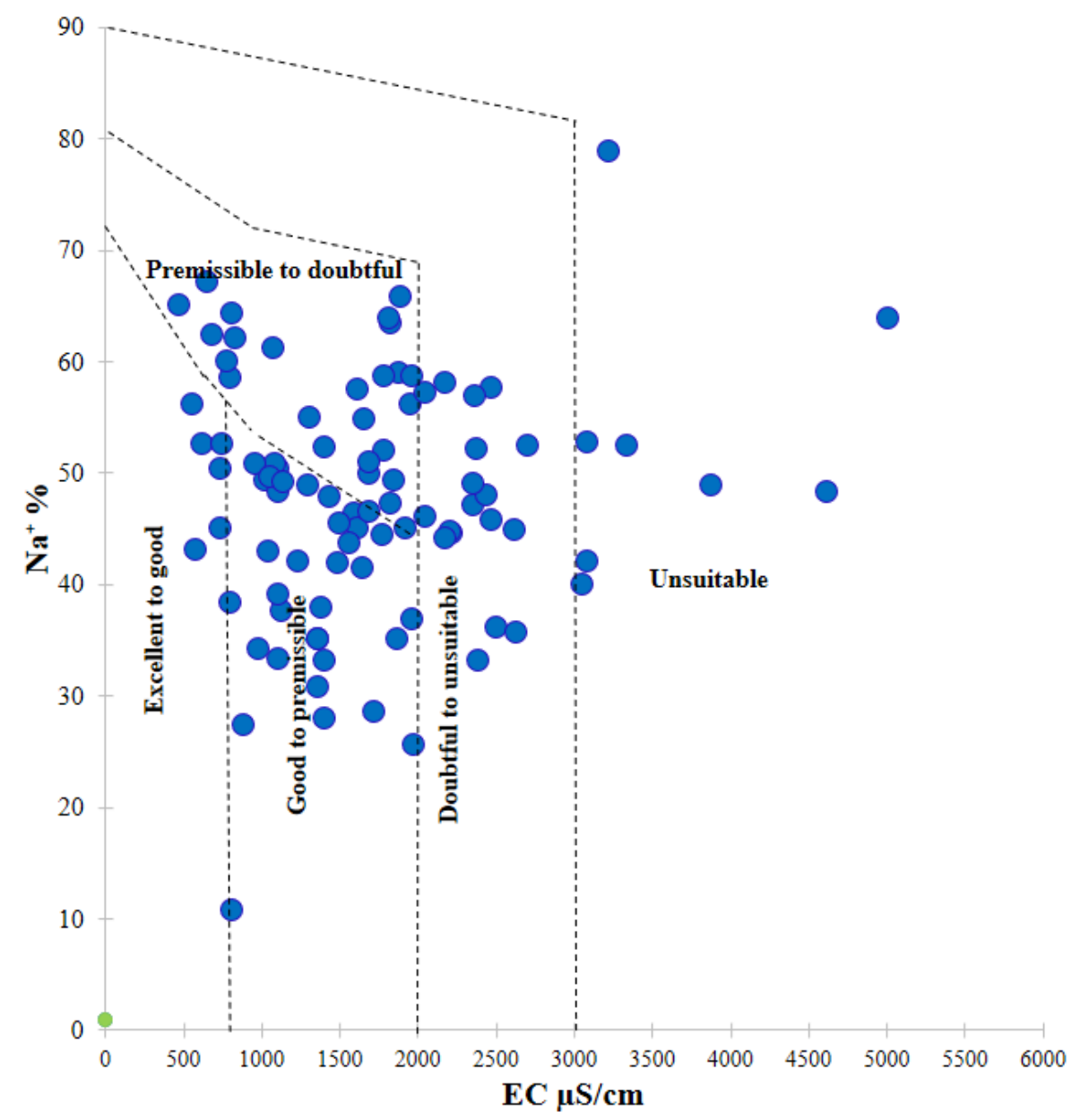

Figure 11. Sodium percentage (\%Na) versus EC (Wilcox 1948).

\subsection{Health Risk Analysis}

Arsenic and iron in groundwater samples were assessed for non-carcinogenic health risks as stated above [74,75]. As a first step, CDI was calculated for both adults and children and As and Fe metals. Later, using these CDI values, the hazard quotient (HQ) $[76,77]$ was calculated for both adults and children and As and Fe metals. The values of hazard quotient in As for children from 0 to 0.000667 and average value 0.000107. Similarly, for adults, the hazard quotient value in arsenic ranged from 0 to 0.000286 with an average value of $4.57 \times 10^{-5}$. For iron, the hazard quotient values in children ranged from 0 to 0.395 , with an average value of 0.00815 , and in adults, these values ranged from 0 to 0.01229 , with an average value of 0.001873 . All these values are shown in Table 9. 
Table 9. Statistical analyses for Health Risk rate (HRR) assessment.

\begin{tabular}{ccccc}
\hline Heavy Metals & Age Group & Minimum & Maximum & Mean \\
\hline Arsenic & Children & 0 & 0.000667 & 0.000107 \\
(As) & Adults & 0 & 0.000286 & $4.5 \times 10^{-5}$ \\
Iron & Children & 0 & 0.395 & 0.00815 \\
(Fe) & Adults & 0 & 0.01229 & 0.001873 \\
\hline
\end{tabular}

These obtained calculations for each sample were observed for chronic risk. As explained previously, the samples with a hazard quotient greater than 1 were thought to show a chronic risk rate and need for treatment [78]. In the obtained samples, the hazard indices for As and Fe in adults were both below 1 and showed negligible to low chronic risk. In other words, almost $100 \%$ of water samples were suitable for health rate assessment in adults. Moreover, in children, about $20 \%$ of the As samples exceeded the range of $\mathrm{HQ}$ that is 1 , but Fe metals had HQ values within the permissible range [79]. Hence about $100 \%$ of groundwater samples being examined showed no health risk in adults and almost $80 \%$ showed no health risk in children, as detailed in Table 10.

Table 10. Chronic Risk and Samples analysis.

\begin{tabular}{|c|c|c|c|c|}
\hline Heavy Metals & Age Group & $\begin{array}{c}\text { Hazard } \\
\text { Quotient (HQ) }\end{array}$ & Chronic Risk & $\begin{array}{c}\text { Number of } \\
\text { Samples }\end{array}$ \\
\hline \multirow{8}{*}{$\begin{array}{c}\text { Arsenic } \\
\text { (As) }\end{array}$} & \multirow{4}{*}{ Children } & $<0.1$ & Negligible & 75 \\
\hline & & $\geq 0.1<1$ & Low & None \\
\hline & & $\geq 1<4$ & Medium & 20 \\
\hline & & $\geq 4$ & High & None \\
\hline & \multirow{4}{*}{ Adults } & $<0.1$ & Negligible & 75 \\
\hline & & $\geq 0.1<1$ & Low & 20 \\
\hline & & $\geq 1<4$ & Medium & None \\
\hline & & $\geq 4$ & High & None \\
\hline \multirow{8}{*}{$\begin{array}{l}\text { Iron } \\
(\mathrm{Fe})\end{array}$} & \multirow{5}{*}{ Children } & $<0.1$ & Negligible & All samples \\
\hline & & $\geq 0.1<1$ & Low & None \\
\hline & & $\geq 1<4$ & Medium & None \\
\hline & & $\geq 4$ & High & None \\
\hline & & $<0.1$ & Negligible & All samples \\
\hline & \multirow{3}{*}{ Adults } & $\geq 0.1<1$ & Low & None \\
\hline & & $\geq 1<4$ & Medium & None \\
\hline & & $\geq 4$ & High & None \\
\hline
\end{tabular}

\section{Conclusions}

Groundwater analysis is being done using different methods and techniques to evaluate the usability of groundwater for irrigation and drinking purposes. The water quality index, Gibbs and Pipers plots, Wilcox, USSL diagram, health risk assessment, ion exchange, and multivariate analysis were used to demonstrate whether the water samples from the region Sakrand, Sindh are safe for human use. The result of following the abundance of ions indicated the cations were in the order $\mathrm{Na}_{+}>\mathrm{Ca}^{2+}>\mathrm{Mg}^{2+}>\mathrm{K}^{+}$and the abundance of anions was in the order $\mathrm{HCO}_{3}{ }^{-}>\mathrm{Cl}^{-}>\mathrm{SO}_{4}{ }^{2-}>\mathrm{NO}_{3}{ }^{-}>\mathrm{F}^{-}$. In the research, the concentration of sodium and bicarbonate ions represents the phenomenon of silicate weathering, which is the control to major ions chemistry of groundwater. The eminent factor to study the quality of groundwater samples for drinking by the WQI, according to which about $67.4 \%$ of samples were found to be excellent and good for drinking and the rest, 32.6\%, were not drinkable. The Gibbs diagram of the study region showed rock dominance due to dissolvable salts and minerals becoming absorbed and assimilated with groundwater. Furthermore, the Piper diagram showed no dominant ions but some samples in cations showed dominance in $\mathrm{Na}_{+}-\mathrm{K}_{+}$type and anions, and some samples showed an observant chemistry of the type $\mathrm{HCO}_{3}{ }^{-}$and $\mathrm{Cl}^{-}$. Overall, most (about 60\%) of the samples laid in 
the 5th region of the graph, which was a mixture of calcium, magnesium, and chloride ions $\left(\mathrm{Ca}^{2+}-\mathrm{Mg}^{2+}-\mathrm{Cl}^{-}\right.$type). The dominant cation was sodium, and the dominant anion was bicarbonate. The ion exchange method showed that forward ion exchange was dominant. Multivariate analysis statistically proved the relation between different variables and their hydrogeochemistry in the groundwater. Similarly, with the sole purpose of the evaluation of the water samples for irrigation purposes, investigated by agricultural indices, showed a high salinity hazard using the USSL diagram. Further investigation on irrigation sampling resulted in $60 \%$ of the sample showing medium to high salinity and low alkalinity hazards. However, the Wilcox diagram indicated that most of the samples were good to permissible for irrigation purposes. Overall, health risk rates were determined in the region and only 20 samples were found to be risky for children. Other than that, all samples were suitable for both children and adults.

Author Contributions: Writing—original draft; M.Y.J.B. and W.Z.; Conceptualization; M.Y.J.B. and W.Z.; J.C.; methodology; M.Y.J.B., J.C. and S.L.; software; M.Y.J.B., E.E.H. and M.A.; formal analysis; G.R., M.Y.J.B. and M.A.; investigation; M.Y.J.B., M.A., M.M. and J.I.; resources; W.Z.; data curation; M.Y.J.B., S.A.T. and J.I.; review and editing; W.Z., E.E.H. and A.T.; visualization; E.E.H., M.A. and A.T.; supervision; W.Z. All authors have read and agreed to the published version of the manuscript.

Funding: This research was funded by [Taif University Researchers Supporting Project] grant number [TURSP-2020/324].

Institutional Review Board Statement: Not applicable.

Informed Consent Statement: Not applicable.

Data Availability Statement: The data presented in this study are available on request from the first or corresponding authors.

Acknowledgments: Authors would like to acknowledge the financial support provided from Taif University Researchers Supporting Project Number [TURSP-2020/324].

Conflicts of Interest: The authors declare no conflict of interest.

\section{References}

1. Slukovskii, Z.; Dauvalter, V.; Guzeva, A.; Denisov, D.; Cherepanov, A.; Siroezhko, E. The hydrochemistry and recent sediment geochemistry of small lakes of Murmansk, Arctic Zone of Russia. Water 2020, 12, 1130. [CrossRef]

2. Egbi, C.D.; Anornu, G.; Appiah-Adjei, E.K.; Ganyaglo, S.Y.; Dampare, S.B. Evaluation of water quality using hydrochemistry, stable isotopes, and water quality indices in the Lower Volta River Basin of Ghana. Environ. Develop. Sustain. 2019, 21, 3033-3063. [CrossRef]

3. Qu, B.; Zhang, Y.; Kang, S.; Sillanpää, M. Water quality in the Tibetan Plateau: Major ions and trace elements in rivers of the “Water Tower of Asia". Sci. Total Environ. 2019, 649, 571-581. [CrossRef] [PubMed]

4. Qureshi, A.S.; Shah, T.; Akhtar, M. The Groundwater Economy of Pakistan; IWMI: Lahore, Pakistan, 2003 ; Volume 64.

5. Memon, S.A.; Sheikh, I.A.; Talpur, M.A.; Mangrio, M.A. Impact of deficit irrigation strategies on winter wheat in semi-arid climate of sindh. Agric. Water Manag. 2021, 243, 106389. [CrossRef]

6. Soomro, A.; Memon, A.; Gadehi, M.; No, E.-S.B. Use of groundwater for agricultural production in Deh Desvi of Thano Boola Khan, Jamshoro, Sindh. Pak. J. Agric. Agril. Engg. Vet. Sci 2010, 26, 60-69.

7. Buschmann, J.; Berg, M.; Stengel, C.; Winkel, L.; Sampson, M.L.; Trang, P.T.; Viet, P.H. Contamination of drinking water resources in the Mekong delta floodplains: Arsenic and other trace metals pose serious health risks to population. Environ. Int. 2008, 34, 756-764. [CrossRef] [PubMed]

8. Chauhan, V.S.; Nickson, R.; Chauhan, D.; Iyengar, L.; Sankararamakrishnan, N. Ground water geochemistry of Ballia district, Uttar Pradesh, India and mechanism of arsenic release. Chemosphere 2009, 75, 83-91. [CrossRef] [PubMed]

9. Daud, M.; Nafees, M.; Ali, S.; Rizwan, M.; Bajwa, R.A.; Shakoor, M.B.; Arshad, M.U.; Chatha, S.A.S.; Deeba, F.; Murad, W. Drinking water quality status and contamination in Pakistan. BioMed Res. Int. 2017, 2017. [CrossRef] [PubMed]

10. Baloch, M.Y.J.; Talpur, S.A.; Talpur, H.A.; Iqbal, J.; Mangi, S.H.; Memon, S.J.J.o.W.; Technology, E. Effects of Arsenic Toxicity on the Environment and Its Remediation Techniques: A Review. J. Water Environ. Technol. 2020, 18, 275-289. [CrossRef]

11. Hussein, E.E.; Fouad, M.; Gad, M.I.J.A.w.s. Prediction of the pollutants movements from the polluted industrial zone in 10th of Ramadan city to the Quaternary aquifer. Appl. Water Sci. 2019, 9, 20. [CrossRef]

12. Hu, P.; Sharifi, A.; Tahir, M.N.; Tariq, A.; Zhang, L.; Mumtaz, F.; Shah, S.H.I.A. Evaluation of Vegetation Indices and Phenological Metrics Using Time-Series MODIS Data for Monitoring Vegetation Change in Punjab, Pakistan. Water 2021, 13, 2550. [CrossRef] 
13. Qiao, B.; Wang, J.; Huang, L.; Zhu, L. Characteristics and seasonal variations in the hydrochemistry of the Tangra Yumco basin, central Tibetan Plateau, and responses to the Indian summer monsoon. Environ. Earth Sci. 2017, 76, 162. [CrossRef]

14. Crosa, G.; Froebrich, J.; Nikolayenko, V.; Stefani, F.; Galli, P.; Calamari, D. Spatial and seasonal variations in the water quality of the Amu Darya River (Central Asia). Water Res. 2006, 40, 2237-2245. [CrossRef]

15. Hildebrandt, A.; Guillamón, M.; Lacorte, S.; Tauler, R.; Barceló, D. Impact of pesticides used in agriculture and vineyards to surface and groundwater quality (North Spain). Water Res. 2008, 42, 3315-3326. [CrossRef] [PubMed]

16. Shah, S.H.I.A.; Yan, J.; Ullah, I.; Aslam, B.; Tariq, A.; Zhang, L.; Mumtaz, F. Classification of Aquifer Vulnerability by Using the DRASTIC Index and Geo-Electrical Techniques. Water 2021, 13, 2144. [CrossRef]

17. Bawoke, G.T.; Anteneh, Z.L. Spatial assessment and appraisal of groundwater suitability for drinking consumption in Andasa watershed using water quality index (WQI) and GIS techniques: Blue Nile Basin, Northwestern Ethiopia. Cogent Eng. 2020, 7, 1748950. [CrossRef]

18. Cao, X.; Lu, Y.; Wang, C.; Zhang, M.; Yuan, J.; Zhang, A.; Song, S.; Baninla, Y.; Khan, K.; Wang, Y. Hydrogeochemistry and quality of surface water and groundwater in the drinking water source area of an urbanizing region. Ecotoxicol. Environ. Safety 2019, 186, 109628. [CrossRef] [PubMed]

19. Gupta, S.D.; Mukherjee, A.; Bhattacharya, J.; Bhattacharya, A. An overview of agricultural pollutants and organic contaminants in groundwater of India. Groundwater South Asia 2018, 247-255.

20. Pacheco Castro, R.; Pacheco Ávila, J.; Ye, M.; Cabrera Sansores, A. Groundwater quality: Analysis of its temporal and spatial variability in a karst aquifer. Groundwater 2018, 56, 62-72. [CrossRef] [PubMed]

21. Zhang, Q.; Xu, P.; Qian, H. Groundwater quality assessment using improved water quality index (WQI) and human health risk (HHR) evaluation in a semi-arid region of northwest China. Expo. Health 2020, 1-14. [CrossRef]

22. Tariq, A.; Shu, H.; Kuriqi, A.; Siddiqui, S.; Gagnon, A.S.; Lu, L.; Linh, N.T.T.; Pham, Q.B. Characterization of the 2014 Indus River Flood Using Hydraulic Simulations and Satellite Images. Remote Sens. 2021, 13, 2053. [CrossRef]

23. Wang, J.; Liu, G.; Liu, H.; Lam, P.K. Multivariate statistical evaluation of dissolved trace elements and a water quality assessment in the middle reaches of Huaihe River, Anhui, China. Sci. Total Environ. 2017, 583, 421-431. [CrossRef] [PubMed]

24. Xiao, J.; Wang, L.; Deng, L.; Jin, Z. Characteristics, sources, water quality and health risk assessment of trace elements in river water and well water in the Chinese Loess Plateau. Sci. Total Environ. 2019, 650, 2004-2012. [CrossRef]

25. Colombo, L.; Alberti, L.; Azzellino, A.; Marina, B. Multi-methodological integrated approach for the assessment of Diffuse Pollution Background Levels (DPBLs) in Functional Urban Areas: The PCE case in Milano NW sector. Front. Environ. Sci. 2020. [CrossRef]

26. Tariq, M.I.; Afzal, S.; Hussain, I. Degradation and persistence of cotton pesticides in sandy loam soils from Punjab, Pakistan. Environ. Res. 2006, 100, 184-196. [CrossRef] [PubMed]

27. Tariq, S.R.; Shaheen, N.; Khalique, A.; Shah, M.H. Distribution, correlation, and source apportionment of selected metals in tannery effluents, related soils, and groundwater-A case study from Multan, Pakistan. Environ. Monit. Assess. 2010, 166, 303-312 [CrossRef] [PubMed]

28. Ullah, R.; Malik, R.N.; Qadir, A. Assessment of groundwater contamination in an industrial city, Sialkot, Pakistan. Afr. J. Environ. Sci. Technol. 2009, 3, 429-446.

29. Rashid, A.; Khan, S.; Ayub, M.; Sardar, T.; Jehan, S.; Zahir, S.; Khan, M.S.; Muhammad, J.; Khan, R.; Ali, A. Mapping human health risk from exposure to potential toxic metal contamination in groundwater of Lower Dir, Pakistan: Application of multivariate and geographical information system. Chemosphere 2019, 225, 785-795. [CrossRef]

30. Baig, J.A.; Kazi, T.G.; Arain, M.B.; Afridi, H.I.; Kandhro, G.A.; Sarfraz, R.A.; Jamal, M.K.; Shah, A.Q. Evaluation of arsenic and other physico-chemical parameters of surface and ground water of Jamshoro, Pakistan. J. Hazard. Mater. 2009, 166, 662-669. [CrossRef] [PubMed]

31. Memon, M.; Soomro, M.S.; Akhtar, M.S.; Memon, K.S. Drinking water quality assessment in Southern Sindh (Pakistan). Environ. Monitor. Assess. 2011, 177, 39-50. [CrossRef]

32. Lanjwani, M.F.; Khuhawar, M.Y.; Jahangir Khuhawar, T.M. Assessment of groundwater quality for drinking and irrigation uses in taluka Ratodero, district Larkana, Sindh, Pakistan. Int. J. Environ. Anal. Chem. 2020, 100, 1-24. [CrossRef]

33. Shahab, A.; Shihua, Q.; Rashid, A.; Hasan, F.U.; Sohail, M.T. Evaluation of Water Quality for Drinking and Agricultural Suitability in the Lower Indus Plain in Sindh Province, Pakistan. Pol. J. Environ. Stud. 2016, 25, 2563-2574. [CrossRef]

34. Salma, S.; Rehman, S.; Shah, M. Rainfall trends in different climate zones of Pakistan. Pak. J. Meteorol. $2012,9,47$.

35. Qureshi, A.S.; McCornick, P.G.; Qadir, M.; Aslam, Z. Managing salinity and waterlogging in the Indus Basin of Pakistan. Agric. Water Manag. 2008, 95, 1-10. [CrossRef]

36. Qureshi, A.; Lashari, B.; Kori, S.; Lashari, G. Hydro-salinity behavior of shallow groundwater aquifer underlain by salty groundwater in Sindh Pakistan. In Proceedings of the Proceedings, Fifteenth International Water Technology Conference, Alexandria, Egypt, 31 March-2 April 2011; pp. 1-15.

37. Afifi, A.; May, S.; Clark, V.A. Computer-Aided Multivariate Analysis; CRC Press: Beijing, China, 2003.

38. Karunanidhi, D.; Aravinthasamy, P.; Subramani, T.; Muthusankar, G. Revealing drinking water quality issues and possible health risks based on water quality index (WQI) method in the Shanmuganadhi River basin of South India. Environ. Geochem. Health 2020, 1-18. [CrossRef] 
39. Boateng, T.K.; Opoku, F.; Acquaah, S.O.; Akoto, O. Groundwater quality assessment using statistical approach and water quality index in Ejisu-Juaben Municipality, Ghana. Environ. Earth Sci. 2016, 75, 489. [CrossRef]

40. Pei-Yue, L.; Hui, Q.; Jian-Hua, W. Groundwater quality assessment based on improved water quality index in Pengyang County, Ningxia, Northwest China. E-J. Chem. 2010, 7. [CrossRef]

41. Neissi, L.; Golabi, M.; Gorman, J. Spatial interpolation of sodium absorption ratio: A study combining a decision tree model and GIS. Ecol. Indic. 2020, 117, 106611. [CrossRef]

42. Kawagoshi, Y.; Hama, T.; Kakimoto, R.; Itomitsu, N.; Hong, N.; Tomiie, K. Nitrate contamination of groundwater and identification of its cause in Kumamoto City and neighbouring area in Japan. Int. J. Food Safety Nutr. Public Health 2016, 6, 14-28. [CrossRef]

43. Dippong, T.; Mihali, C.; Hoaghia, M.-A.; Cical, E.; Cosma, A. Chemical modeling of groundwater quality in the aquifer of Seini town-Somes Plain, Northwestern Romania. Ecotoxicol. Environ. Saf. 2019, 168, 88-101. [CrossRef]

44. Rehman, J.U.; Ahmad, N.; Ullah, N.; Alam, I.; Ullah, H. Health Risks in Different Age Group of Nitrate in Spring Water Used for Drinking in Harnai, Balochistan, Pakistan. Ecol. Food Nutr. 2020, 59, 462-471. [CrossRef]

45. Rezaei, H.; Zarei, A.; Kamarehie, B.; Jafari, A.; Fakhri, Y.; Bidarpoor, F.; Karami, M.A.; Farhang, M.; Ghaderpoori, M.; Sadeghi, H.; et al. Levels, Distributions and Health Risk Assessment of Lead, Cadmium and Arsenic Found in Drinking Groundwater of Dehgolan's Villages, Iran. Toxicol. Environ. Health Sci. 2019, 11, 54-62. [CrossRef]

46. Tahir, M.; Rasheed, H. Fluoride in the drinking water of Pakistan and the possible risk of crippling fluorosis. Drink. Water Eng. Sci. 2013, 6, 17-23. [CrossRef]

47. He, S.; Wu, J. Hydrogeochemical characteristics, groundwater quality, and health risks from hexavalent chromium and nitrate in groundwater of Huanhe Formation in Wuqi county, northwest China. Exposure Health 2019, 11, 125-137. [CrossRef]

48. Khalid, S. An assessment of groundwater quality for irrigation and drinking purposes around brick kilns in three districts of Balochistan province, Pakistan, through water quality index and multivariate statistical approaches. J. Geochem. Explor. 2019, 197, 14-26.

49. Azis, A.; Yusuf, H.; Faisal, Z.; Suradi, M. Water turbidity impact on discharge decrease of groundwater recharge in recharge reservoir. Procedia Eng. 2015, 125, 199-206. [CrossRef]

50. Rao, N.S.; Sunitha, B.; Adimalla, N.; Chaudhary, M. Quality criteria for groundwater use from a rural part of Wanaparthy District, Telangana State, India, through ionic spatial distribution (ISD), entropy water quality index (EWQI) and principal component analysis (PCA). Environ. Geochem. Health 2020, 42, 579-599.

51. Cloutier, V.; Lefebvre, R.; Therrien, R.; Savard, M.M. Multivariate statistical analysis of geochemical data as indicative of the hydrogeochemical evolution of groundwater in a sedimentary rock aquifer system. J. Hydrol. 2008, 353, 294-313. [CrossRef]

52. Talpur, S.A.; Noonari, T.M.; Rashid, A.; Ahmed, A.; Jat Baloch, M.Y.; Talpur, H.A.; Soomro, M.H. Hydrogeochemical signatures and suitability assessment of groundwater with elevated fluoride in unconfined aquifers Badin district, Sindh, Pakistan. SN Appl. Sci. 2020, 2, 1-15. [CrossRef]

53. Talib, M.A.; Tang, Z.; Shahab, A.; Siddique, J.; Faheem, M.; Fatima, M. Hydrogeochemical characterization and suitability assessment of groundwater: A case study in Central Sindh, Pakistan. Int. J. Environ. Res. Public Health 2019, 16, 886. [CrossRef]

54. Subramani, T.; Rajmohan, N.; Elango, L. Groundwater geochemistry and identification of hydrogeochemical processes in a hard rock region, Southern India. Environ. Monit. Assess. 2010, 162, 123-137. [CrossRef]

55. Barzegar, R.; Moghaddam, A.A.; Nazemi, A.H.; Adamowski, J. Evidence for the occurrence of hydrogeochemical processes in the groundwater of Khoy plain, northwestern Iran, using ionic ratios and geochemical modeling. Environ. Earth Sci. 2018, 77, 597. [CrossRef]

56. Mgbenu, C.N.; Egbueri, J.C. The hydrogeochemical signatures, quality indices and health risk assessment of water resources in Umunya district, southeast Nigeria. Appl. Water Sci. 2019, 9, 1-19. [CrossRef]

57. Mukherjee, A.; Fryar, A.E. Deeper groundwater chemistry and geochemical modeling of the arsenic affected western Bengal basin, West Bengal, India. Appl. Geochem. 2008, 23, 863-894. [CrossRef]

58. Reyes-Toscano, C.A.; Alfaro-Cuevas-Villanueva, R.; Cortés-Martínez, R.; Morton-Bermea, O.; Hernández-Álvarez, E.; BuenrostroDelgado, O.; Ávila-Olivera, J.A. Hydrogeochemical characteristics and assessment of drinking water quality in the urban area of Zamora, Mexico. Water 2020, 12, 556. [CrossRef]

59. Amiri, V.; Sohrabi, N.; Dadgar, M.A. Evaluation of groundwater chemistry and its suitability for drinking and agricultural uses in the Lenjanat plain, central Iran. Environ. Earth Sci. 2015, 74, 6163-6176. [CrossRef]

60. Giglioli, S.; Colombo, L.; Contestabile, P.; Musco, L.; Armiento, G.; Somma, R.; Vicinanza, D.; Azzellino, A.J.W. Source apportionment assessment of marine sediment contamination in a post-industrial area (Bagnoli, Naples). Water 2020, $12,2181$. [CrossRef]

61. Satyaji Rao, Y.; Keshari, A.K.; Gosain, A.J.I.J.o.E.; Management, W. Evaluation of regional groundwater quality using PCA and geostatistics in the urban coastal aquifer, East Coast of India. Water 2010, 5, 163-180.

62. Tank, D.K.; Chandel, C.S.J.N. Science Analysis of the major ion constituents in groundwater of Jaipur city. Pollution Res. 2010, 8 , $1-7$.

63. Liu, J.; Gao, Z.; Wang, Z.; Xu, X.; Su, Q.; Wang, S.; Qu, W.; Xing, T.J.E.m. Assessment Hydrogeochemical processes and suitability assessment of groundwater in the Jiaodong Peninsula, China. Environ. Monit. Assess. 2020, 192, 1-17. [CrossRef] 
64. Ewaid, S.H.; Mhajej, K.G.; Abed, S.A.; Al-Ansari, N. Groundwater Hydrochemistry Assessment of North Dhi-Qar Province, South of Iraq Using Multivariate Statistical Techniques. In Proceedings of the IOP Conference Series: Earth and Environmental Science, Surakarta, Indonesia, 24-25 August 2021; p. 012075.

65. Roy, B.; Roy, S.; Mitra, S.; Manna, A.K.J.A.J.o.G. Evaluation of groundwater quality in West Tripura, Northeast India, through combined application of water quality index and multivariate statistical techniques. Water 2021, 14, 1-18. [CrossRef]

66. Sadat-Noori, S.; Ebrahimi, K.; Liaghat, A. Groundwater quality assessment using the Water Quality Index and GIS in SavehNobaran aquifer, Iran. Environ. Earth Sci. 2014, 71, 3827-3843. [CrossRef]

67. Ahsan, W.A.; Ahmad, H.R.; Farooqi, Z.U.R.; Sabir, M.; Ayub, M.A.; Rizwan, M.; Ilic, P. Surface water quality assessment of Skardu springs using Water Quality Index. Environ. Sci. Pollution Res. 2021, 28, 1-12. [CrossRef] [PubMed]

68. Ramírez-Morales, D.; Pérez-Villanueva, M.E.; Chin-Pampillo, J.S.; Aguilar-Mora, P.; Arias-Mora, V.; Masís-Mora, M. Pesticide occurrence and water quality assessment from an agriculturally influenced Latin-American tropical region. Chemosphere 2021, 262, 127851. [CrossRef]

69. Nagarajan, R.; Rajmohan, N.; Mahendran, U.; Senthamilkumar, S. Evaluation of groundwater quality and its suitability for drinking and agricultural use in Thanjavur city, Tamil Nadu, India. Environ. Monitor. Assess. 2010, 171, 289-308. [CrossRef] [PubMed]

70. Zhou, Y.; Li, P.; Xue, L.; Dong, Z.; Li, D. Solute geochemistry and groundwater quality for drinking and irrigation purposes: A case study in Xinle City, North China. Geochemistry 2020, 125609. [CrossRef]

71. Seth, R.; Mohan, M.; Singh, P.; Singh, R.; Dobhal, R.; Singh, K.P.; Gupta, S.J.A.W.S. Water quality evaluation of Himalayan rivers of Kumaun region, Uttarakhand, India. Appl. Water Sci. 2016, 6, 137-147. [CrossRef]

72. Singh, K.R.; Goswami, A.P.; Kalamdhad, A.S.; Kumar, B. Development of irrigation water quality index incorporating information entropy. Environ. Dev. Sustain. 2020, 22, 3119-3132. [CrossRef]

73. Esmeray, E.; Gökcekli, C. Assessment of groundwater quality for drinking and irrigation purposes in Karabuk province, Turkey. Environ. Earth Sci. 2020, 79, 1-17. [CrossRef]

74. Khalid, S.; Shahid, M.; Shah, A.H.; Saeed, F.; Ali, M.; Qaisrani, S.A.; Dumat, C. Heavy metal contamination and exposure risk assessment via drinking groundwater in Vehari, Pakistan. Environ. Sci. Pollution Res. 2020, 27, 39852-39864. [CrossRef]

75. ur Rehman, I.; Ishaq, M.; Ali, L.; Muhammad, S.; Din, I.U.; Yaseen, M.; Ullah, H. Potentially toxic elements' occurrence and risk assessment through water and soil of Chitral urban environment, Pakistan: A case study. Environ. Geochem. Health 2020, 1-14. [CrossRef] [PubMed]

76. Chattopadhyay, A.; Singh, A.P.; Singh, S.K.; Barman, A.; Patra, A.; Mondal, B.P.; Banerjee, K. Spatial variability of arsenic in Indo-Gangetic basin of Varanasi and its cancer risk assessment. Chemosphere 2020, 238, 124623. [CrossRef]

77. Saha, N.; Rahman, M.S. Groundwater hydrogeochemistry and probabilistic health risk assessment through exposure to arseniccontaminated groundwater of Meghna floodplain, central-east Bangladesh. Ecotoxicol. Environ. Saf. 2020, 206, 111349. [CrossRef]

78. Barakat, A.; Hilali, A.; Baghdadi, M.E.; Touhami, F. Assessment of shallow groundwater quality and its suitability for drinking purpose near the Béni-Mellal wastewater treatment lagoon (Morocco). Hum. Ecol. Risk Assess. Int. J. 2020, 26, 1476-1495. [CrossRef]

79. Shahab, A.; Qi, S.; Zaheer, M. Arsenic contamination, subsequent water toxicity, and associated public health risks in the lower Indus plain, Sindh province, Pakistan. Environ. Sci. Pollution Res. 2019, 26, 30642-30662. [CrossRef] 